\title{
PROMISES PAST: MARCUS ATILIUS REGULUS AND THE DIALOGUE OF NATURAL LAW
}

\author{
WILLIAM R. NIFONG* \\ Ó Fides alma ápta pinnis ét ius iurandúm Iovis! $!^{1}$
}

\section{INTRODUCTION}

We begin with two Roman stories-one ancient and now arcane, one modern and yet notorious. One recounts the heroism of a single man; the other convenes embassies from a majority of the world's nations. Notwithstanding a bridge of more than two millennia, a common theme emerges from these two remote and seemingly dissimilar episodes-a lesson about the sanctity of promise-keeping between sovereign peoples. ${ }^{2} \mathrm{Be}$ it the oath of a lone prisoner of war or a proud nation's refusal to sign an international constitutive document, these diplomatic choices offer compelling evidence of how a people conceives of itself in relation to the other, as well as of its notions of justice and collective honor. Perhaps more than anything else, these shared values, these ideals, guide and inform every promise madeor not made-between peoples, and they dictate the manner in which that promise will be honored. To illuminate this point, I turn to the stories to which I have already alluded: the legendary faithfulness of

* To my father, C. Roy Nifong, Jr. . . . for his example. My gratitude is owed to Professor Herbert Bernstein, Duke University School of Law, for his patient guidance and for his review of my translations from the German; to Lawrence Richardson, jr, James B. Duke Professor of Latin, Emeritus, Duke University, for his erudition, his generous spirit, and his continued inspiration; and especially to Sandra Antognoli, who lent to this endeavor both the keen eye of a historian and the untiring devotion of a friend.

1. CiCERO, DE OfFICIIS 3.29.104 (Walter Miller trans., Harvard Univ. Press 1913) (44 B.C.) ("Gracious Good Faith, on wings upborne; thou oath in Jupiter's great name!" (quoting the Roman poet Ennius, 239-169 B.C.)).

2. I have chosen to use the term "peoples," rather than "states" or "nations," for two reasons: (1) much of the material discussed in this Note pertains to the period of the Roman Republic (509-27 B.C.), long before the concept of the nation-state emerged; (2) I seek to avoid the conclusion that I am in any way arguing for a revival of nationalism, as it is generally understood. Having begun this Note, I discovered that John Rawls made a similar choice in a recently published book. For his reasoning, see JOHN RAWLS, THE LAW OF PEOPLES 23-30 (1999). 
Marcus Atilius Regulus and the Rome Conference for establishing the International Criminal Court ("ICC").

The Ancient. In the middle of the third century B.C., Rome found herself embroiled in a struggle for control of the Mediterranean world. In retrospect, it was inevitable that Rome would clash with mighty Carthage, the mercantile and naval power of North Africa and the only real threat to the ascendant Roman dominion over the region. ${ }^{3}$ Although history has privileged the second, and arguably the most decisive, of the three Punic Wars, ${ }^{4}$ the second-century-B.C. historian Polybius relates that the First Punic War (264-241 B.C.) was "the longest, most unintermittent, and greatest war" of memory. It is in this context that one encounters the venerable history of Marcus Atilius Regulus.

As consul suffectus in 256 B.C., ${ }^{6}$ Regulus defeated the Carthaginian fleet at Ecnomus and proceeded straightaway to invade Africa, capturing the city of Tunis. His trouble then began. On the heels of Carthage's rejection of rather punishing terms of peace, the Roman army was routed by Spartan mercenary forces, and Regulus was taken prisoner. The prevailing tradition ${ }^{7}$ holds that the commander was soon dispatched to Rome to seek the release of Carthaginian prisoners being held in Italy. What is most significant, however, is that he had sworn a solemn oath to return to his captors if he failed to persuade the Senate to abide by the Carthaginians' wishes. Not only

3. For a full analysis of the causes and progress of the conflict, see FRITZ M. Heichelheim et Al., A History of the Roman People 81-90 (2d ed. 1984).

4. Heichelheim provides the dates of the Punic Wars: First (264-241 B.C.), Second (218201 B.C.), and Third (148-146 B.C.). See id. at 81, 100, 127. The Second Punic War was the one in which Hannibal improvidently led his infantry and elephants across the Alps. See id. at 102.

5. Polybius, Histories 1.63.4-5 (W.R. Paton trans., Harvard Univ. Press 1922) (ca. 150 B.C.). For Polybius' full account of the war, see id. at 1.10-64.

6. A consul suffectus was appointed to serve out the one-year term of a consul who had died. Regulus, having been elected consul for the year 267 B.C., was well qualified and highly respected. See "Atilius (RE 51) Regulus, Marcus," in THE OXFORD Classical DiCTIONARY 207 (Simon Hornblower \& Antony Spawforth eds., 3d ed. 1996) (offering an ample modern summary of Regulus' career).

7. Polybius appears not to know of Regulus' embassy to Rome, nor of his subsequent return to Carthage to be tortured to death. See POLYBIUs, supra note 5, at 1.26-35 (recounting Regulus' role in the First Punic War (264-241 B.C.)); see also THE OXFORD ClassicaL DICTIONARY, supra note 6, at 207 (stating that Regulus likely died "of natural causes"). For a far more detailed discussion of the Regulus story, as well as other ancient and modern sources, see infra Part II.B.

Please note that, for purposes of dating ancient texts, I rely on biographical information for each author as provided in THE OXFORD CLASSICAL DICTIONARY, supra note 6. Where little or nothing is known about the dates of the works themselves, I offer the dates of the authors' lives. 
did Regulus fail, but he himself implored the Senate not to yield to the enemy's demands. Whereupon Regulus, of his own free will, set sail for Carthage and prepared to meet an agonizing death. With his noble sacrifice, however, he purchased everlasting fame. Having so captured the Western imagination, the nobility of Regulus has been lauded by writers from the Augustan poet Horace to John Milton. ${ }^{8}$ Artists of the seventeenth, eighteenth, and nineteenth centuries have memorialized him on canvas. ${ }^{9}$ His name even appears in a handful of early American court opinions. ${ }^{10}$

The Modern. Let us fast-forward about 2250 years, to the summer of 1998, when the world again turned its eyes to Rome. Delegations from 162 nations had gathered in the ancient capital to deliberate about, and ideally to establish, a new international tribunal. The front page of France's Le Monde heralded their success, declaring, "An International Criminal Court Is Born."11 After weeks of grueling, often impassioned negotiations ${ }^{12}$ - and many decades of proposals and aspirations ${ }^{13}-120$ countries, a near three-fourths majority of the nations attending the conference, voted to approve the charter of the ICC. ${ }^{14}$ The court, sitting in the Hague, will officially come into being when sixty countries have ratified the treaty, ${ }^{15}$ and it will exercise ju-

\footnotetext{
8. See infra notes 139-49 and accompanying text.

9. See infra notes 144-48 and accompanying text.

10. See, e.g., Williams' Case, 29 F. Cas. 1330, 1332 (C.C.D. Conn. 1799) (No. 17,708) (citing the Regulus episode, as recorded in Justinian's Digest 49.15.1.3).

11. Une cour pénale internationale est née, LE MONDE, July 19-20, 1998, at 1. Please note that I shall provide in the footnotes the original foreign language text whenever I offer my own
} translations for quotation.

12. See Tom McFeely, The Ultimate Activist Court Collapses, AlberTA REP./NEWSMAGAZINE, June 27, 1998 (pinpoint unavailable) (chronicling the failure of a Canadian "homosexual-feminist agenda," which would, inter alia, have criminalized government bans on abortion); infra notes 237-38 and accompanying text (discussing the objections of the United States).

13. See Une cour pénale internationale est née, supra note 11, at 1 (noting that calls for such a body began with the human rights struggle at the turn of the century: "[L]es sources remontent aux combats humanistes du début du XXe siècle.").

14. See 120 Staaten für Weltgerichtshof [120 Nations for World Court], DIE WELT, July 20, 1998, at 7. For the complete text of the charter, see Rome Statute of the International Criminal Court, U.N. Diplomatic Conference of Plenipotentiaries on the Establishment of an International Criminal Court on July 17, 1998, U.N. Doc. A/CONF. 183/9, reprinted in 37 I.L.M. 999 (1998) [hereinafter Rome Statute].

15. For the latest update on the number and identity of countries having signed and ratified the Rome Statute, see the Coalition for an International Criminal Court's ("CICC") website, The CICC International Criminal Court Home Page (visited May 26, 2000) $<\mathrm{http} / /$ www.igc.apc.org/icc/index.html > (on file with the Duke Law Journal). Currently, there are 96 signatories and 10 ratifications (Senegal, Trinidad and Tobago, San Marino, Italy, Fiji, Ghana, Norway, Belize, Tajikistan, and Iceland). See id. 
risdiction over four categories of offenses: genocide, crimes against humanity, war crimes, and crimes of aggression..$^{16}$ Although one commentator proclaimed the creation of the court "a major step forward for the universal conscience," ${ }^{17}$ the United States, resolutely opposed to certain terms of the charter, turned its back and went home. ${ }^{18}$

Admittedly, these two anecdotes differ in a number of respects. In the first, a promise was made and honored at great personal cost by a single Roman citizen; in the second, the United States' negotiators opted not to make a promise on behalf of 250 million Americans. That which I hope to expose in this rather odd juxtaposition is a fundamental principle of natural $\operatorname{law}^{19}$ — that promises made between sovereign peoples are sacred and properly inviolable. Neither Regulus' conduct nor that of the American delegation to the Rome Conference can be divorced from their respective societies' notions of justice and collective honor. Far from aberrant, Regulus' choice reflected a distinctively Roman understanding of natural law, a philosophical, moral, and legal conception of good faith that underlay the construction of Roman-ness and of the Roman name. Fidelity to promises made by a Roman to an "other" redounded to the reputation and to the glory of Rome. In that respect, the American decision in Rome, even if for very different reasons, was also appropriate. Promises by which a people cannot abide should never be made in the first place.

Dionysius of Halicarnassus defined history as philosophy from examples. ${ }^{20}$ I seek to demonstrate that the principles, and hence the true epistemology, of natural law ultimately derive from a cumulative analysis of those examples. This is the dialogue of natural law. Given their prominence in intellectual discourse up to the middle of this century, Roman ideals, in particular, must be reconsidered. Goethe once observed that the ius civile, or Roman civil law, was like "a diving duck which hides itself from time to time but never wholly disap-

16. See Rome Statute, supra note 14, art. 5, 37 I.L.M. at 1003-04.

17. Une cour pénale internationale est née, supra note 11, at 1 (quoting French Prime Minister Lionel Jospin: “«un progrès majeur de la conscience universelle»”).

18. See infra notes 232-38 and accompanying text (discussing the world reaction to the United States' position, American objections to the Rome Statute, and the significance of American opposition).

19. For a general discussion of natural law theory and its development, see infra Part I.A.

20. See Dionysius of Halicarnassus, Roman AntiQuities 9.1-2 (Earnest Cary trans., Harvard Univ. Press 1937) (ca. 7 B.C.). 
pears and always comes to the fore again." ${ }^{21}$ Certainly, when the scholar Trebonianus passed the completed Pandects to Justinian in December of 533 A.D., he preserved not only the ius civile but also the natural law philosophy and other traditions of ancient Rome. ${ }^{22}$ I argue for a reclamation of that inheritance and a recrudescence of the uniquely Roman natural law doctrine of promise-keeping.

To that end, Part I of this Note will return to the languishing debate concerning natural law. If, as one scholar claims, "the current desuetude of natural law philosophy is mistaken as a matter of intellectual history, ${ }^{, 23}$ it would seem equally misguided, if not dangerous, to exclude voices from outside the halls of jurisprudence. ${ }^{24}$ In addition to considering the disquisitions of traditionally recognized natural law theorists and philosophers, I shall marshal the thoughtful considerations of writers, poets, and even artists to illustrate the dialogic method of discerning the natural law and the sanctity of the promise as understood therein. Part II will focus on religious and political institutions in ancient Rome dedicated to the faithful stewardship of promises, and it will concentrate especially on the interpretations of the Regulus story and what it reveals about the natural law duties and expectations of individuals as parties to promises made by them or on their behalf. By way of comparison and assessment, Part III will turn to the legacy of this natural law tradition as it has been received in the United States and will revisit briefly the American role at the Rome Conference. Although recent history suggests that we have abandoned natural law and the sacred respect for promises, there is some cause for optimism.

In all likelihood, this Note will appear more nostalgic than innovative, as much an exhortation as a reasoned argument. Less than one hundred years ago, its message would have been so obvious as to be otiose. That indeed is the point. Among the Romans, the mos

21. Robert Feenstra, Law, in THE LEGACY OF RoME 399, 399 (Richard Jenkyns ed., 1992) (recording Goethe's description of Roman law).

22. This episode was of such moment that Raphael memorialized the scene in a Vatican fresco. See James Beck, Raphael: The Stanza Della Segnatura 74-75 (1993) (including Raphael's fresco Trebonianus Handing the Pandects to Justinian (1511)). On commission from Pope Julius II, Raphael adorned the walls of the Stanza at the same time that Michelangelo was painting the Sistine Chapel. See id. at 8.

23. Francis J. Mootz, III, Law in Flux: Philosophical Hermeneutics, Legal Argumentation, and the Natural Law Tradition, 11 YALE J.L. \& HUMAN. 311, 313 (1999).

24. See Benjamin Sells, The Soul of the Law 50 (1994) (outlining the prevalence and the damaging effects of an excessively narrow legal perspective). Sells remarks that "[b]ecause non-legal experiences cannot help but remind the lawyer of his or her broader connections to the world beyond the Law, such experiences, like bad recruits, must be drummed out." Id. 
maiorum, or the custom of the ancestors, communicated identity, meaning, and purpose. It also provided lessons about honor and justice-not always fully enlightened truths, perhaps, but important contributions to the ongoing human dialogue. As John Stuart Mill so eloquently reminds us, "[t]he great authority for political doctrines in ['the best constituted commonwealths of antiquity'] was the wisdom of their ancestors: their old laws, their old maxims, the opinions of their ancient statesmen." ${ }^{25}$ The wisdom of our own must emerge from a reassessment of theirs.

\section{BACK TO NATURAL LAW}

Natural law theories rest on the belief "that there is a natural order within the universe, that it is possible to ascertain the existence and nature of this order ... and that human laws should and do flow" therefrom. ${ }^{26}$ One needs no background in legal history or theory to recognize that to lay claim to the "natural" is potentially to harness the authority and the rhetorical force of the divine. To identify the natural, however - and to persuade others of the wisdom and security of that definition-is another matter altogether. Looking briefly at the current state of natural law theory, I shall examine both the definitional challenges of the natural law and, in my view, that which historically has proven its greatest weakness: a conviction that natural lawyers are able to isolate eternal principles of natural law with scientific precision and conclusiveness. To the contrary, I wish to posit that numerous ancient and modern sources contemplate a process of discovery that is both dynamic and dialogic, a discussion that welcomes the voices and insights not just of legal scholars, but of all able minds. Even if the natural never changes, our comprehension thereof must rely as much on well-tested tradition as on revelation. Finally, within that natural law dialogue, we shall encounter in the writings of historians, philosophers, and poets a fundamental principle embraced centuries ago by the Romans and dutifully espoused up to our own time-that promises made between sovereign peoples are sacred.

25. John Stuart Mill, The Spirit of the Age, in Mill 3, 28-29 (Alan Ryan ed., W.W. Norton 1997) (1831).

26. George C. Christie \& Patrick H. Martin, Jurisprudence 8-9 (2d ed. 1995). 


\section{A. Defining and Defending the "Natural"}

In the view of many modern commentators, natural law-as set forth by the likes of Hugo Grotius, Samuel Pufendorf, and Emerich de Vattel $^{27}$ - has been relegated to the yellowed annals of legal history. Statist conceptions of international law and legal positivism have asserted that the only legitimate basis for international law is the express or implied consent of states, as evidenced by treaties and other agreements, customary practice, and universally recognized, or peremptory, norms. ${ }^{28}$ Admittedly, this orientation fosters some greater degree of certainty and predictability; without doubt, focusing on what is, rather than what ought to be, is more comfortable. ${ }^{29}$ In contrast, "the natural law tradition appears to be hopelessly confused and anachronistic in the brave new world of postmodern legal the-

27. For classic natural law treatises, see HUGo Grotius, THE LAw OF WAR AND PEACE [DE JURE Belli ET PACIS] (Louise R. Loomis trans., W.J. Black 1949) (1625); SAMUEL Pufendorf, On the Duty of Man and Citizen According to Natural Law [De Officio Hominis et Civis JuXTa Legem Naturalem] (James Tully ed. \& Michael Silverthorne trans., Cambridge Univ. Press 1991) (1673); EMERICH DE VATTEL, THE LAW OF Nations [Le Droit Des Gens] (Joseph Chitty ed. \& trans., Phila., T. \& J.W. Johnson 1876) (1758). For the most notable American efforts in the twentieth century, see JOHN FINNIS, NATURAl Law AND Natural Rights (1980); LON L. Fuller, The Morality OF THE LAW (1969); Lon Fuller, Human Purpose and Natural Law, 53 J. PHIL. 697 (1956); see also ANTHONY J. LissKa, Aquinas's TheOry of NATURAL LAW 21 (1996) (recognizing Lon Fuller as "the principal exponent of natural law among legal scholars in the United States at mid-century").

28. Peremptory norms of international law are referred to as ius cogens norms. Comprising prohibitions such as those against genocide and crimes against humanity, these norms are justified not merely by the moral outrage with which they are regarded around the world, but also by a theory of implied consent based on long-established international practice and belief. For a thorough analysis of ius cogens norms, see Jack Alan Levy, As Between Princz and King: Reassessing the Law of Foreign Sovereign Immunity as Applied to Jus Cogens Violators, 86 GEO. L.J. 2703, 2705-07 (1998).

Natural law theories require no evidence of consent to be bound. Whether divine, moral, ethical, or some combination thereof, the justifications for natural law principles are independent of the will of states and individuals. Cicero recognized this difference and proclaimed that custom and law were in no wise to be regarded as equivalent to natural law and justice. See Cicero, De Legibus 1.15.42, in De Re Publica And De Legibus 287, 343 (Clinton Walker Keyes trans., Harvard Univ. Press 1928) (ca. 51-54 B.C.) ("But the most foolish notion of all is the belief that everything is just which is found in the customs or laws of nations."). As argued later in this Note, the natural law evolves through time as a dialogue among legal theorists, philosophers, and others. See infra Part I.B. At any given point in time, the "natural" within the legal order will be that era's best approximation of natural justice. (Sometimes, as in the case of slavery and other practices, mistakes are made.) Based on the behavior of states, customary law and ius cogens norms may indeed overlap with the natural law, but the prevailing view has been that natural law will always anticipate and motivate progress in international law.

29. John Austin, the leading exponent of the statist view of international law, has criticized Grotius and Pufendorf for confusing what is with "their own vague conceptions of international morality as it ought to be." See 1 JOHN AUSTIN, LECTURES ON JURISPRUDENCE (R. Campbell ed., 5th ed. 1885) (1832), quoted in CHRISTIE \& MARTIN, supra note 26, at 517, 581. 
ory. ${ }^{" 30}$ In the realm of political pragmatism and expedience, it has fared little better. Senator Daniel Patrick Moynihan has wistfully remarked that in the Congress of today "[r]eal men [do not] cite Grotius." ${ }^{31}$

The source of much of the confusion about natural law has resulted from natural law philosophers' inability to proffer a single, coherent deontological proof of natural law-that is, from what authority natural law arises and why it must be binding on human beings. On a closely related point, they have also disagreed about the definition of natural justice and its relationship to divine law. In antiquity, Cicero avowed that "Law is not a product of human thought, nor is it any enactment of peoples, but something eternal which rules the whole universe by its wisdom in command and prohibition." ${ }^{, 32}$ Under this view, divine and natural law are conflated, including that of the ius gentium, the law of nations. ${ }^{33}$

Although most theorists have included divine law in their respective classifications, Grotius suggested that natural law, as a precondition to well-ordered human society, would be binding even in the absence of a god. ${ }^{34}$ For the sake of clarity, I simply adopt Senator Moynihan's description of natural law: "Divine, if you please. Natural, if you like. In the view of many, both." ${ }^{35}$ I shall not attempt here to resolve these age-old dilemmas. In fact, as I urge later, that is the task of history, of the ongoing natural law dialogue. Let it suffice to say that each generation has found its voices in defense of the enterprise of natural law, those who, like Thomas Jefferson, "appeal[ed] to the true fountains of evidence, the head \& heart of every rational \& honest man[, where] Nature has written her moral laws, \& where every man may read them for himself."

30. Mootz, supra note 23, at 312.

31. DANiEl PATRICK MOYNihan, On the LaW OF NATIONS 7 (1990).

32. CiCERO, De Legibus, supra note 28, at 2.4.8.

33. See VATtel, supra note 27, at vii-viii (discussing the Romans' "confounding" of natural law and the law of nations). After assessing more recent theoretical classifications, Vattel suggests that a special subcategory of natural law is required for international law, or the ius gentium. See id. at viii-xvii.

34. See Sir Hersch Lauterpacht, The Grotian Tradition in International Law, 23 BRIT. Y.B. INT'L L. 1, 53 n.1 (1946).

35. MOYNIHAN, supra note 31 , at 9 .

36. ThOMAS JEFFERSON, Opinion on the French Treaties (Apr. 28, 1793) [hereinafter JefFERSON, Opinion], in Writings 422, 423 (Merrill D. Peterson ed., Library of America 1984). 
In point of fact, what Goethe said of the irrepressible Roman civil law is no less true of the natural law doctrine that emerged parallel to it: natural law is the philosophy that, as they say, just will not die. I believe that its pertinacity, its resilience, stems from the very quality that alternately causes it to be spurned: its grounding in faith. Indeed, natural law theories must rest on faith, whether in a supreme being or simply in the fundamental goodness of humanity and its capacity for mutual happiness and justice. Where there exists a core understanding of these principles and these aims, there is no need for absolute dependence on positive law. Thus, one might hazard a characterization of natural law theorists as idealists, even dreamers-and not in the least disparagingly. As Cicero noted, humanity stands ever in need of virtue..$^{37}$ Ultimately, it is the voice of natural law that reemerges to challenge the positivists to expect more and to do more; it is that voice that challenges us to be better. Sir Hersch Lauterpacht, a noted international law theorist of the twentieth century, opined that natural law "satisfie[s] the craving, in the jurist and the layman alike, for a moral content in the law." ${ }^{38}$

Unquestionably, this inclination breeds messiness. A welter of religious differences, conflicting political views, and otherwise discordant elements awaits any person who dares to argue for restoration of a moral content, a moral force, in law, be it domestic or international. $^{39}$ In its uncertainty, the ongoing debate over natural law also challenges many of the attitudes, principles, and ways of thinking most dear to the legal profession. As Benjamin Sells has observed, the law "tends to empty ordinary experience of its passionate, emotional, and imaginative aspects-all of which are seen by the Law as interfering with its own definitions of stability, consistency, and predictability." ${ }^{, 0}$ Nevertheless, it is passion, emotion, and imagination that animate the dialogue of natural law.

\section{B. The Dynamic Dialogue of Natural Law}

Although Grotius and other natural law philosophers were often associated with the idea of progress and innovation in international

37. See CiCERo, De Re Publica 1.1.1, in De Re PubliCA AND De Legibus, supra note 28, at 1, 15 (declaring that "Nature has implanted in the human race so great a need of virtue ... that the strength thereof has conquered all the allurements of pleasure and ease").

38. Lauterpacht, supra note 34, at 52.

39. See infra note 60 and accompanying text (considering the discomfiture with natural law that has caused some jurisprudes to abandon it altogether).

40. SELLS, supra note 24 , at 181. 
law, ${ }^{41}$ their theories betray a similarly conservative preoccupation with certitude. By defining the "natural" as eternal and fixed, they promised finality in the proper isolation and articulation of natural law principles. Cicero averred that " $[\mathrm{t}]$ rue law is right reason in agreement with nature; it is of universal application, unchanging and everlasting." ${ }^{42} \mathrm{He}$ also believed that he could identify it. Vattel echoed this view: "[A]s this law is immutable, and the obligations that arise from it necessary and indispensable, nations can neither make any changes in it by their conventions, dispense with it in their conduct, nor reciprocally release each other from the observance of it." ${ }^{43}$ Admittedly, such absolutism cannot withstand the proofs of human experience, and it is arguably this hidebound devotion to the immutability of natural law that has proven the Achilles heel of most natural law theories.

Since the most cursory review of history will gather a host of damning contradictions, instances in which the "natural" eventually ceased to be so, any lasting construction of natural law must account for fundamental changes in the belief systems of civilizations. For instance, in Vattel's eighteenth-century world, slavery and other practices now considered evils, or customs antithetical to natural justice, were tolerated by societies and even endorsed by natural law philosophers. Although differing philosophically, both Cicero and Thomas Jefferson endorsed the "natural" practice of slavery. ${ }^{44}$ Natural law theories must address this inherent and vexing inconsistency. If this law of nature is to be regarded as law that transcends time, as well as cultural and political boundaries, it cannot be convincingly argued that the entire content of natural law set forth at a given moment is static, nor that one philosopher has forever isolated these

41. See Lauterpacht, supra note 34 , at 52.

42. CiCERo, De Re Publica, supra note 37, at 3.22.33.

43. VATTEL, supra note 27, at lviii.

44. See Cicero, ON Duties 18 n.3 (M.T. Griffin \& E.M. Atkins eds., Cambridge Univ. Press 1991) (44 B.C.) (confirming the Roman view of slave status as a product of fortune, not nature, and observing an opinion prevalent among the Romans that slaves should be treated as "permanent employees"); THOMAS JEFFERSON, Notes on the State of Virginia: Query XIV (Feb. 27, 1787), in WRITINGS, supra note 36, at 256, 267-68 (arguing that African-American slaves were marked by nature, as well as distinguishing many Roman slaves from those of the United States: "Epictetus [a Stoic philosopher], Terence [a comic playwright], and Phaedrus [a fabulist], [sic] were slaves. But they were of the race of whites."). It bears noting that by the time of Jones v. Van Zandt, 46 U.S. (5 How.) 215 (1847), natural law arguments against the practice of slavery were being adopted by the abolitionists. See Brief of Salmon P. Chase, at 94, reprinted in 1 Fugitive Slaves AND AMERICAN COURTs 341, 434 (Paul Finkelman ed., 1988) (asserting that "every court is bound, by prior and superior obligations, to abstain from enforcing [unjust] law"). 
principles. From a neo-Platonist perspective, one might argue that there are indeed certain eternal, "natural" principles of law and that each generation of lawyers and legal scholars attempts to describe them, to incorporate them into their legal systems-at least to the extent that contemporary values, norms, and attitudes will permit. At best, this is an approximation, with the omnipresent hope that each succeeding age will draw nearer to the "just."

To uncover the roots of this evolutionary theory of human perception, one need only turn to the writings of Plato himself. Although Plato arguably influenced Cicero more profoundly than any other philosopher, ${ }^{45}$ it seems that the otherwise-able pupil and, in turn, Cicero's own devotees misapprehended the master in one critical respect: the ability of human beings, or of human reason, to grasp, once and for all, the essence of the natural. When Plato expounded the well-known "Theory of Forms," he contemplated that the guardians of his ideal republic would be able to perceive the "form," or the true essence, of the beautiful, the honorable, and other abstract principles, including the just. His metaphor of choice was one of sleep: "[M]ost people... are asleep and dreaming, whereas the philosopher has 'woken up to' the Forms." " This is an unmistakable image of enlightenment. However, enlightenment need not be a sudden, final episode of revelation. It may, in fact, only initiate a gradual process of perception, a series of epiphanies. This interpretation of Plato now has much currency. Julia Annas has cautioned "that Forms are not the end of a journey of faith, beaming out certainty and security to a passive audience. They are the beginning of an intellectual quest ... a breaking out of passive conformity to intellectual liberation." ${ }^{47}$ This opinion also finds support in the writings of Aristotle, who recognized the existence of eternal principles but confessed doubt about the infallibility of human reason: "[A]ll law is universal[,] but about some things it is not possible to make a universal statement which shall be correct." ${ }^{48}$

45. For a fine discussion of Cicero's philosophical orientation, see ELIZABETH RAWSON, CiCERo 233-37 (1975). In general, Cicero is labeled "loyal to the outlook of the New Academy as represented by Philo [the Skeptic], with certain eclectic, mainly Stoic, modifications." Id. at 236.

46. Julia Annas, An Introduction to Plato's Republic 240 (rev. ed. 1987). For Plato's discussion of the "Theory of Forms," see PLATO, Republic 5.474b-480a, 7.521-525, 10.596a-597e, in THE COLleCted Dialogues 575, 713-20, 753-58, 820-23 (Edith Hamilton \& Huntington Cairns eds. \& Paul Shorey trans., Princeton Univ. Press 1961) (ca. 384-370 B.C.).

47. ANNAS, supra note 46, at 240.

48. ARISTOTLE, Nicomachean Ethics 5.10.10-15, in THE BASIC WORKS OF ARISTOTLE 927, 1020 (Richard McKeon ed., Random House 1941) (ca. 335-322 B.C.). 
As many minds are always more reliable than one, legal systems and cultures have often relied upon discussion and debate for formulating, applying, and interpreting the law. This is no less true with respect to the discernment of natural law. Despite an overweening confidence in his own mental, legal, and moral acumen, Cicero acknowledged the necessity of the collective hermeneutic process in law. He regarded the jurists, those legal experts on whom Roman judges relied for guidance, as a "second level of law." ${ }^{49}$ Their practice of issuing opinions, or responsa, was known as the ius respondendi. Naturally, these jurists, much as our own, often disagreed about the interpretation of both the Roman civil law and the tenets of natural law. Moreover, in ancient Rome, the elected judge, or praetor, was required to issue an edict, a handbook of causes of action and of procedural guidelines for his one-year term of office. As they included cases outside the domain of the ius civile proper, later referred to as causes in equity, these edicts in some measure became annual declarations of natural law. ${ }^{50}$ According to Sir Henry Sumner Maine, a widespread enthusiasm for natural law discourse in the late Republic further resulted in a perception of praetorial edicts as instruments for restoring the natural law. ${ }^{51}$ To some degree, therefore, each praetor was able to enact his own version of the natural law and, if his ideas were well received, to leave a permanent mark on Roman doctrine.

While Grotius, Pufendorf, and even John Locke upheld the irrefutability of enunciated natural law principles, each of them also postulated that the content of that law must be determined by "discourse among the learned," 52 sometimes loosely termed the ius prudentium. It is unclear at what point the conversation of the wise was to end, or at what point the natural law principles would be deemed

49. BRUCE W. FrIER, THE RISE OF THE Roman JURISTS 185 (1985) (analyzing Cicero's view of the sources of and authority for Roman law, as outlined in the Pro Caecina of 69 B.C.). Within 50 years of Cicero's assassination, Augustus Caesar reportedly made the opinions of certain favored jurists binding in the tribunals of Rome. See BARRY NichOLAS, AN INTRODUCTION TO ROMAN LAW 31 (1962).

50. See Sir Henry Sumner Maine, Ancient Law 56-57 (London, John Murray 1861).

51. See id.

52. CHRISTIE \& MARTIN, supra note 26, at 191. One might also note the role of intellectual inquiry and expert opinions during the 11th-century revival of Roman law. See David S. Clark, The Medieval Origins of Modern Legal Education: Between Church and State, 35 AM. J. CoMP. L. 653, 686 (1987) (reporting that Abélard "brought together for each question the conflicting opinions of various authorities" and that he believed "that by doubting we are led to inquiry, and by inquiring we attain truth"); id. at 691 (discussing the function of consilia, expert opinions routinely sought in the course of lawsuits). 
fixed..$^{53}$ Apparently recognizing the rather arbitrary and counterintuitive nature of this epistemology, Thomas Jefferson remarked that "[t]hose who write treatises of natural law, can only declare what their own moral sense \& reason dictate in the several cases they state... [W]here [Grotius, Pufendorf, and Vattel] differ, \& they often differ, we must appeal to our own feelings and reason to decide between them." ${ }^{, 54}$ In this regard, the sage Founding Father anticipated the critical modern scholarship of figures such as Hans-Georg Gadamer and Chaim Perelman, who have recast legal epistemology in terms of hermeneutical and rhetorical analyses. ${ }^{55}$ Professor Francis Mootz has described their theory as "rhetorical knowledge," 56 and his apt characterization closely patterns the dialogic process of natural law that I have envisioned:

Rhetorical knowledge can be defined as the effort of two or more persons working together creatively to refashion the linguistically structured symbols of social cohesion.... This activity is at once hermeneutical and rhetorical, for it involves both discernment and expression, both understanding and proposing, and both active listening and speaking. Rhetorical knowledge is a practical achievement that neither achieves apodictic certitude nor collapses into a relativistic irrationalism; rhetorical knowledge therefore sustains legal practice as a reasonable-even if not thoroughly rationalizedsocial activity. ${ }^{57}$

Summoning one of the most eminent external voices in this dialogue, I offer the wisdom of Walt Whitman: "Law is the unshakable order of the universe forever; and the law over all, and law of laws, is the law of successions; that of the superior law, in time, gradually supplanting and overwhelming the inferior one." ${ }^{, 58}$ There can be little doubt of the identity of meaning between Whitman's law of succes-

53. Other legal traditions have struggled with this problem as well. Within Islamic jurisprudence, for instance, there has been a centuries-old debate about the role of scholarly consensus in determining principles of law (a process known as ijm $\bar{a}^{\prime}$ ), particularly with respect to which voices must be included in that consensus and at what point a legal principle is to be accepted. See Wael B. HallaQ, IslamiC Legal THeORIES 75-81 (1997). These questions are of extreme importance because a principle of law thus identified is considered by most scholars to be settled for all time. See id.

54. JEFFERSON, Opinion, supra note 36, at 428.

55. See Mootz, supra note 23, at 323-24.

56. Id. at 323 .

57. Id. at 323-24 (citation omitted).

58. Walt Whitman, Democratic Vistas, in Complete Poetry and Collected Prose 929, 948 (Justin Kaplan ed., Library of America 1982) (1892). 
sions and the evolving natural law discussed herein. Thus, the most compelling epistemological theory of natural law will likely emerge as a meta-epistemology. That is to say, the only convincing construction of natural law and the manner in which it is discerned, will be one of discourse, a diachronic process of gathering the multiple theories of natural law developed by countless philosophers throughout history. Each successive theory will add new insights, truths, and modifications to those preceding it. In the end, the method by which each individual attains, or claims to attain, that knowledge, will not matter very much at all.

Although natural law is currently out of fashion in the United States, there is an argument to be made that such a dynamic natural law dialogue uniquely models that of a treasured American experiment - that of free speech. First Amendment jurisprudence maintains that public discourse, even potentially dangerous discussion, is the surest path to truth. Learned Hand staunchly defended such unfettered dialogue when he said, "[T]he First Amendment... presupposes that right conclusions are more likely to be gathered out of a multitude of tongues, than through any authoritative selection. To many this is, and always will be, folly; but we have staked upon it our all." ${ }^{, 59}$ So, too, with natural law. Only the forum is much larger and the cost of failure more dear. We cannot abjure our responsibility and withdraw from this dialogue simply because morality is an evercontentious subject, especially on the international plane. ${ }^{60} \mathrm{I}$ believe that if Learned Hand had considered Plato's guardians in light of the foregoing analysis, as "intellectually liberated" individuals engaged in the dialogue of natural law, he might well have welcomed them, instead of mistrusting them. ${ }^{61}$ In short, the only real-albeit criticaldifference between an absolutist theory of natural law and that for which I now argue is that the one projects the arrogance of putative certainty and the other keeps the conversation going.

59. United States v. Associated Press, 52 F. Supp. 362, 372 (S.D.N.Y. 1943).

60. See, e.g., Robert Bork, The Limits of “International Law", 18 NAT'L INTEREST, Winter 1989 , at 3,10 (arguing that "[t]here can be no authentic rule of law among nations until nations have a common political morality or are under a common sovereignty").

61. See LEARNED HAND, THE BiLl OF Rights 73 (1958) ("For myself it would be irksome to be ruled by a bevy of Platonic Guardians, even if I knew how to choose them, which I assuredly do not."). 


\section{Promise-Keeping as a First Principle of Natural Law}

If any lasting principle of natural law has issued from centuries of consideration and discourse, it is that promises between sovereign peoples are sacred. In fact, many philosophers have regarded this fidelity as the sine qua non of international law. As Professor Lauterpacht has noted, the Grotian conception of natural law presupposed "the obligation to abide by pacts [as] ... the essence of the social contract. Without it the social contract is meaningless. As such, the obligation to keep promises is the principal tenet of the law of nature." ${ }^{, 2}$ Vattel seconded this opinion, asserting that this duty of faith is "as necessary as it is natural and indubitable, between nations that live together in a state of nature." ${ }^{, 3}$ Vattel communicates that even Mohammed entreated his followers to adhere faithfully to treaties. ${ }^{64} \mathrm{In}$ the modern era, this principle has found its most well-known expression in Article 26 of the Vienna Convention on the Law of Treaties. Entitled "Pacta Sunt Servanda," the provision declares that "[e]very treaty in force is binding upon the parties to it and must be performed by them in good faith." ${ }^{65}$

Unfortunately, a number of articles following Article 26 prove that the "necessity" of fidelity to treaties is no longer absolute, nor are treaty obligations always scrupulously preserved. ${ }^{66}$ This has been the all-too-common practice, if not the doctrine, among sovereign peoples for centuries. However, only recently has the practice of nations - that is, an increasing laxity with respect to faithful promisekeeping-found expression and sanction in the doctrine of international law. Prior to the eclipse of natural law theory by positive international law, the world community's damning censure of the faithless promisor testified to the sacredness of such promises as convincingly as its praise of the faithful and its untiring defense of the natural law principle.

Openly cynical about the efficacy of treaties and disdainful of princes who failed to abide by them, Sir Thomas More and the citizens of his Utopia eschewed treaty-making altogether. For them,

\footnotetext{
62. Lauterpacht, supra note 34, at 42.

63. VATTEL, supra note 27, at 195.

64. See id. at $196 \mathrm{n}^{*}$.

65. Vienna Convention on the Law of Treaties, May 23, 1969, 1155 U.N.T.S. 331, 339. Although the United States signed the treaty on April 24, 1970, it is important, at least symbolically, to recognize that it has never been ratified.

66. See id. art. 56 (denunciation), arts. 57-58 (suspension), arts. 59-64 (termination), 1155 U.N.T.S. at 345-47.
} 
promises (in the form of treaties, pacts, or other agreements) were binding even in the absence of the traditional formalities: "For what is the purpose of a treaty?... It is as if nature does not put enough love between man and man. If a man scorns nature, do you think he would care about words?" ${ }^{67}$ Other commentators, philosophers, and writers have extended this obligation to implied promises as well. Vattel and Grotius both discuss the binding nature of these tacit pledges ${ }^{68}$ and Western literature is replete with chronicles decrying their breach, particularly when such treachery occurs in war. For instance, even though Homer's polymetis 'wily' Odysseus found honor among the Greeks for the brilliant stratagem of the Trojan horse-an implied pledge of armistice and peace-Dante consigned him to everlasting torment and retribution. ${ }^{69}$

Unquestionably, sovereign peoples sometimes commit outright breaches of their obligations to others. Far more often, however, they attempt to weasel out of them by tortured interpretations of documents, flimsy claims of necessity, and other ruses. ${ }^{70}$ In response to these self-serving acts of utility, Vattel offers a stinging rebuke:

He that resorts to such an expedient, either impudently sports with that sacred faith, or sufficiently evinces his inward conviction of the degree of moral turpitude annexed to the violation of it : he wishes to act a dishonest part, and yet preserve the character of an honest man : he is a puritanical impostor, who aggravates his crime by the addition of a detestable hypocrisy. ${ }^{71}$

67. Sir Thomas More, Utopia 95 (Peter K. Marshall trans., Wash. Square Press 1965) (1516).

68. See VATTEL, supra note 27, at 235 (discussing both his own view of tacit promises and Grotius' notion of the "mute sign").

69. See DANTE's Inferno 212 (Tom Phillips trans., Thames \& Hudson 1985) (ca. 1321). Dante relegates Ulysses and Diomedes to hell for their treachery: "United by this retribution now, / as formerly by rage, they go their way. / Inside their common flame their groans recall / the exploit of the horse ... . Inside it too they weep for their deceit." Id.

70. See MORE, supra note 67, at 95 ("[Parties] easily find some verbal quibble, and occasionally formulate treaties deliberately in ambiguous language, so that they can never be bound by firm ties without having some loophole for wriggling out of the treaty and their good faith at the same time."). For a 19th-century American example, see HELEN HUNT JACKSON, A CEntury of Dishonor 225 (Univ. of Okla. Press, 1995) (1881) (noting the "loophole" in an 1859 treaty with the Winnebagoes: "[T]he President . . . shall have full power to modify or change any of the provisions of former treaties ... in such manner and to whatever extent he may judge to be necessary and expedient for [the Winnebagoes'] welfare and best interest."). Jackson rightly doubts that this provision was ever seen by the Winnebagoes. See id.; see also infra notes 217-19 and accompanying text (returning to Jackson's critique of the United States' fidelity to treaties made with Native Americans).

71. VATTEL, supra note 27, at 234. 
Indeed, those who seek to dissemble earn the condemnation of the natural law and the opprobrium of humanity. Gathering a long list of negative exempla, or models, from history, ${ }^{72}$ Vattel recounts the deceit of Tamerlane, the fourteenth-century Mongol warrior. ${ }^{73}$ After securing the capitulation of the city of Sebastia by promising to shed no blood, he ordered all of the enemy soldiers to be buried alive. In the judgment of both Cicero and Vattel, such clever frauds "only serve to aggravate the guilt of the perfidious wretch who has recourse to them." ${ }^{74}$

As these authoritative voices have declared, a promise offered between sovereign peoples must be preserved with the utmost diligence and devotion. The long tradition regarding treaty obligations, good faith to both express and implied pledges, and the sanctity of the ius gentium emerges therefrom as a first principle of natural law. The reverence with which it is addressed in the ancient, Renaissance, and later sources belies any dismissal of the principle with labels of comity or mere respect for custom. It speaks to the natural law of social stability, moral responsibility, and-most strikingly among the ancient Romans-personal and collective honor.

\section{PROMISE-KEEPING AMONG THE ROMANS: THEORY AND PRACTICE}

"The vow and the oath, the Romans' most sacred forms of contract, were wagers or bets in which one staked one's head, one's eyes, one's reputation." 75 All the more so when those vows and oaths implicated the honor of Rome herself, as well as that of all Roman citizens. $^{76}$ Cognizant of the responsibility of faith, Pompeius Magnus, the able general and Julius Caesar's rival, reportedly committed many of

72. Many of these are taken directly from Roman history. See id. at 234-35.

73. See id. at 249. For a full, dramatic treatment of the Tamerlane story, as well as for evidence of its cultural impact, see CHRISTOPHER MARLOWE, TAMBURLAINE THE GrEAT (Basil Ashmore ed., Blandford Press 1948) (1590).

74. VATtel, supra note 27, at 249; accord CICERO, DE OfFICIIS, supra note 1, at 3.32.113 ("[F]or deceit does not remove the guilt of perjury-it merely aggravates it.").

75. Carlin A. Barton, The "Moment of Truth" in Ancient Rome: Honor and Embodiment in a Contest Culture, StAN. Human. Rev., Summer/Autumn 1998, at 16, 16.

76. Among the Romans, contractual promises-as bonds between individuals and commercial enterprises-were never regarded with the same reverence, and there were many more acceptable reasons for abandoning them. See, e.g., CICERO, DE OFFICIIS, supra note 1, at 3.9295 (discussing the morality of breaking a promise "not to dance in the forum," promises made to the subsequently insane, etc.). 
Rome's promises to memory. ${ }^{77}$ To be sure, the preservation of the nomen Romanum, the pristine reputation of Rome, had become a first priority not only of illustrious Romans but also of Rome's religious and political institutions. ${ }^{78}$

In his ode eulogizing Marcus Atilius Regulus, the Roman poet Horace specifically credited the hero with mindfulness of that name. ${ }^{79}$ Regulus had forfeited his life both to uphold a promise and to magnify the honor of Rome. Such praise would doubtless have resonated with the Roman public, who had fed on a steady diet of the mos maiorum, that body of customs and exempla borrowed from their ancestors. Serving a didactic as well as a patriotic end, these stories taught Romans how to be Roman ${ }^{80}$ Livy even claimed that this was the purpose of studying, and perhaps of writing, history. ${ }^{81}$ In all of these lessons, the message was crystal clear: oaths are sacred, and Romans must not break them.

In order to place the Regulus legend in its proper context, it is necessary first to examine the ancient Roman conception of Fides, or Faith, in the broadest sense-the expression and scope of this duty,

77. See Cicero, Pro Balbo 6.15, in Orations: Pro Caelio, De ProvinciIs Consularibus, AND Pro Balbo 611, 641 (R. Gardner trans., Harvard Univ. Press 1958) (speech delivered in 56 B.C.) (praising Pompey's "most remarkable knowledge of treaties, of agreements, of terms imposed upon peoples, kings, and foreign races"). This is the vanquished Pompey eulogized by Marullus in the opening scene of Shakespeare's Julius Caesar: "Many a time and oft / Have you climb'd up to walls and battlements, / To towers and windows, yea, to chimney-tops, / Your infants in your arms, and there have sat / The live-long day, with patient expectation, / To see great Pompey pass the streets of Rome ...." William SHAKESPEARE, Julius CAESAR act 1, sc. 1, in THE COMPLETE WORKS OF William SHAKESPEARE 813, 813 (Avenel Books 1975) (1599) [hereinafter THE COMPLETE WORKS].

78. I discussed this subject at length with Lawrence Richardson, jr, James B. Duke Professor of Latin, Emeritus, Duke University, on November 17, 1999. His learned observations about the Romans' commitment to preservation of the nomen Romanum, reflected here, provided the catalyst for much of the research and analysis that follow infra.

79. See Horace, Carmina 3.5.10-11, in OdES AND EPODES 195, 195 (C.E. Bennett trans., Harvard Univ. Press rev. ed. 1968) (ca. 23 B.C.) (hailing the "the Roman name, the toga, and eternal Vesta" as symbols of Rome's greatness).

80. See Charles William Fornara, The Nature of History in Ancient Greece AND ROME 116-17 (1983) (arguing that the Roman rhetorical purpose of moral exempla helped to legitimize a historiographical focus on individuals' lives, as well as their deeds). For a thorough assessment of the antiquarian tradition in the last century B.C., see ELIZABETH RAWSON, INTELLECTUAL LIFE IN THE LATE RoMAN REPUBLIC 233-49 (1985).

81. See Livy, Ab Urbe Condita 1.10-11 (B.O. Foster trans., Harvard Univ. Press 1919) (27-19 B.C.) ("What chiefly makes the study of history wholesome and profitable is this, that you behold the lessons of every kind of experience set forth as on a conspicuous monument....”). My own philosophical and political reservations aside, I note that conservative William Bennett has sought a similar didactic revival in his compendium of ethical models from literature. See THE BOOK OF VIRTUES passim (William J. Bennett ed., 1993) (collecting stories of courage and honor, from Aesop to Charles Dickens). 
its communication to the citizenry, and its enforcement within Roman society. The philosophy and teachings of Cicero, as the champion of Regulus, will then serve to focus the discussion on the natural law duty of good faith in promise-keeping between sovereign peoples. I shall also offer both ancient and modern responses to Regulus' heroism to argue for the long pedigree of this duty as an established principle within the dialogue of natural law.

\section{A. The Roman Concept of Good Faith}

On the Capitoline Hill in Rome, that most hallowed political and religious center of the ancient city, ${ }^{82}$ there stood a temple to the goddess Fides. ${ }^{83}$ Livy credits Rome's second king, Numa Pompilius (715672 B.C.), with the introduction of the cult of Fides. ${ }^{84}$ The temple itself was dedicated by the middle of the third century B.C., and it was restored by Marcus Aemilius Scaurus during Cicero's lifetime. ${ }^{85}$ In addition to using the sacred space for occasional meetings of the Senate, the Romans proclaimed their dutiful attention to obligations by displaying here the laws and treaties of Rome engraved on bronze tablets. ${ }^{86}$ Christoph Reusser has observed that the Roman conception of faith-and, consequently, the province of the goddess Fides-encompassed everything from fidelity in marriage to contractual obligations and a soldier's commitment to the state.$^{87}$ In the realm of external politics, faith denoted "an adherence to treaties, the protection of

82. See John E. Stambaugh, The AnCiEnt Roman City 221-22 (1988) (describing the procession and ceremony inaugurating the Roman civil year, during which the two consuls ascended the Capitoline Hill and sat down before the temple of Jupiter Optimus Maximus, where they sacrificed two white bulls). The temple of Jupiter Optimus Maximus was the most sacred temple in Rome, having been dedicated by the Tarquins at the end of the Roman Monarchy, circa 509 B.C. See id. at 12-13. The Senate also held its first meeting of the year in the temple, "under Jupiter's supervision." Id. at 222. Even the formal "triumphs," parades granted by the Senate to honor victorious generals, terminated on the Capitoline. See id. at 238-39.

83. See L. Richardson, JR, A New TopographicAl Dictionary of Ancient Rome 151 (1992). The temple was also known as Fides Publica (Public Faith) and Fides Publica Populi Romani (Public Faith of the Roman People). See id.

84. See LIVY, supra note 81, at 1.21.3-4.

85. See RICHARDSON, supra note 83 , at 151 (positing a third-century date for construction of the original temple and suggesting a restoration date of 58 B.C.). The extant decorative elements of the temple have been dated to this later phase, narrowed to a period between the late second century and the middle of the first century B.C. See CHRISTOPH REusSER, DeR Fidestempel auf Dem KaPitol in Rom und Seine Ausstattung [The Temple of Fides IN ROME AND ITS DECORATION] 128 (1993).

86. See RICHARDSON, supra note 83 , at 151 .

87. See REUSSER, supra note 85 , at 53 . 
ambassadors, [and] the precept of lawful warfare." 88 In short, Fides stood " in the center of the political, social, and legal order of Rome' and is even considered 'the most important key to the Roman value system.", 89

The expressions of Fides in Roman society were certainly both bountiful and potent. In addition to the anthropomorphization and worship of Fides on the Capitoline, there were numerous institutionalized mechanisms for both teaching and preserving good faith. For the purposes of this discussion, I shall divide these cultural instruments into three broad categories: (1) cultural and historical tradition, (2) religion, and (3) political, or state, practice. I shall conclude by noting ways in which the Romans, as well as later observers, attributed her greatness to the faithful observance of Fides.

1. The Guiding Hand of the Past. Perhaps the most efficacious vehicle for transmitting and inculcating Roman values was the mos maiorum. Comprising an assemblage of exemplary Romans from legend, history, and that shadowy area in between, this ancestral code of behavior inspired in Romans of the Republic a reverence approaching religious fervor. Its parade of heroes and antiheroes, albeit several centuries removed from Cicero's age, spoke with unparalleled authority in delineating the course of the Roman state and in guiding the actions of upright citizens. Thus, to hearken to the valor of Regulus was not mere nostalgia or sentimentality, but recourse to the dictates of conscience and of tradition. More often than not, the most prominent figures typified an awareness of or disregard for Fides.

Two individuals from the fifth century B.C., Cincinnatus and Coriolanus, are representative of this phenomenon, and their stories have enjoyed enduring popularity in Western culture. Cincinnatus was the rustic and patriot who, in the military crisis of 458 B.C., abandoned his fields to accept a rare six-month dictatorship. Having led Rome to a brilliant defeat of the menacing Aequi after only sixteen days, he resigned from his post and returned to his farm across the Tiber, thereby evincing his love for Rome and his utter lack of political ambition. ${ }^{90}$ Coriolanus, on the other hand, proved a villain

88. Id. ("Einhalten der Verträge, Schutz der Verhandlungsdelegationen, Gebot zur gerechten Kriegführung").

89. Id. at 54 ("[S]tand fides im «Zentrum der politischen, sozialen und rechtlichen Ordnung Roms» und gilt sogar als der «wichtigste Schlüssel zum römischen Wert-system.»" (quoting Viktor Pöschl, Politische Wertbegriffe in Rom, 26 ANTIKE Und ABENDLAND 1, 3 (1980))).

90. See LIVY, supra note 81, at 3.26.6 to 3.29.7. 
and a traitor. After he was driven from Rome in 488 B.C. amidst strife between the social classes, Coriolanus not only sought refuge among a people hostile to his homeland but even led a Volscian army to the walls of Rome in order to exact vengeance. ${ }^{11}$ Livy records the words of the young man's mother, who reproached her son as he prepared to destroy the city: "[H]ad I not been a mother Rome would not now be besieged! Had I no son I should have died a free woman, in a free land! But I can have nothing now to suffer which could be more disgraceful to you or more miserable for myself ...." ${ }^{92}$ At last Coriolanus' Roman heart yielded to his mother's entreaty, and he withdrew once more into exile. ${ }^{93}$

Few things indeed could have evoked equal revulsion in the minds of Romans. Therefore, it is not at all surprising-but rather eminently reasonable-that Coriolanus' betrayal was both recorded and reiterated. Likewise, the patriotism of Cincinnatus became an indispensable element of Roman history, culture, and education. These stories provided critical lessons about good faith and about public honor. In Rome, both were necessary to the successful maintenance of one's image, one's persona. As Carlin Barton has defined it, "[t]he persona was composed of the reputation (existimatio, fama, and nomen), supported by effective energy (virtus) and enforced by a sensitivity to shame (pudor)." ${ }^{94}$ Cincinnatus, of course, became the epitome of republican virtus, or virtue; Coriolanus illustrated the ultimate surrender to pudor, or shame. The frequent reworking of these stories and their messages of good faith by the heirs to the Roman tradition attests to their emotional and rhetorical force. Shakespeare, for example, fashioned a tragedy about Coriolanus, ${ }^{95}$ and eighteenthcentury painter Giambattista Tiepolo juxtaposed the tales of Cincinnatus and Coriolanus in companion canvasses adorning a Venetian

91. See id. at 2.33.3 to 2.40.12 (reporting that Coriolanus died in exile); PluTARCH, Coriolanus, in MAKERS OF ROME 15, 52 (Ian Scott Kilvert ed. \& Betty Radice trans., Penguin Books 1965) (ca. 50-120 A.D.) (recording Coriolanus' death at the hands of the Volscians, which better comports with Roman attitudes towards traitors, even those who would assist them).

92. LivY, supra note 81, at 2.40.8-9.

93. See id. at 2.40.9-10.

94. Barton, supra note 75, at 19.

95. See William SHAKESPEARE, CORIOlAnUS act 5, sc. 3 (speech of Coriolanus' mother), in THE COMPLETE WORKS, supra note 77, at 773, 808 (1607-1609):

Thou know'st, great son, / The end of war's uncertain; but this certain, / That, if thou conquer Rome, the benefit / Which thou shalt thereby reap is such a name, / Whose repetition will be dogg'd with curses; / Whose chronicle thus writ,-The man was noble, / But with his last attempt he wip'd it out; / Destroy'd his country; and his name remains / To the ensuing age abhorr'd .... 
palace. ${ }^{96}$ All who watched Shakespeare's play or viewed Tiepolo's works would have been reminded of the obligations of good faith-of the honor of dutiful service and of the infamy attending its neglect. Less than a quarter-century after Tiepolo's rendering, Cincinnatus would reemerge across the Atlantic as the sobriquet of an American patriot and Antifederalist. ${ }^{97}$ To appropriate the name of Cincinnatus was to don the mantle of republican virtue.

2. Religion and the Fetial Tradition. In addition to the mos maiorum and its powerful socializing effects, there were manifold religious and legal institutions among the Romans dedicated to the preservation and observance of good faith, both with their fellow men and with the gods. Highly legalistic, even contractual, Roman religion held that painstakingly formal, ritual worship of the gods not only would curry favor with the supreme beings but also would bind them in support of Rome's endeavors. ${ }^{98}$ This delicate state of divine endorsement was known as the pax deum, the peace of the gods, ${ }^{99}$ and Roman religion, law, and politics became inextricably linked in the state's effort to maintain it. ${ }^{100}$

Among the ancient priestly societies of Rome, one was dedicated to nothing other than the performance of sacred rites in making treaties and in declaring war. Known as fetiales, or fetials, these religious figures were not career clergy, but rather leading citizens and politicians who became expert in this particular area of the sacral law. ${ }^{101}$ Vattel described the fetials as "priests of the public faith." 102 Like so many other religious traditions in Rome, the institution was reputedly imported by Numa Pompilius. ${ }^{103}$ When the early Romans wished to

96. See Giambattista Tiepolo 1696-1770, at 89 (plate 12b) (Keith Christiansen ed., 1996) (reproducing Tiepolo's Veturia Pleading with Coriolanus (ca. 1726-1728), on display in the Hermitage, St. Petersburg); id. at 91 (plate 12d) (presenting Tiepolo's Cincinnatus Offered the Dictatorship (ca. 1726-1728), also held by the Hermitage). Both canvasses originally decorated the family palace of Venetian nobleman Daniele IV Dolfin. See id. at 86.

97. See 6 The Complete Anti-Federalist 5-33 (Herbert J. Storing ed., 1981) (reproducing essays by "Cincinnatus").

98. See R.J. GOAR, CiCERO AND THE STATE RELIGION 11 (1972).

99. See id. at 12-13.

100. See MARY BeARD \& Michael Crawford, Rome in the LATE RePublic 33 (1985) (stating that "in Rome all formal political activity took place in an explicitly religious context").

101. See id. at 30 (explaining the unique position of priests in Rome).

102. VATTEL, supra note 27, at viii.

103. See DiOnYsiUs OF HALICARNASSUS, supra note 20, at 2.72. Dionysius reports that the fetial tradition had been linked to both the Rutulian city of Ardea and the Aequicoli, an Italic tribe. See id. Elsewhere the introduction of the fetials is attributed to the third king, Tullus Hos- 
establish a treaty with a foreign people, a fetial called the verbenarius, or vervain bearer, traveled to the other party's territory carrying a piece of vervain, an herb native to the Capitoline, with the soil from the sacred precinct still attached. ${ }^{104}$ This plant was given to the foreign representative as a symbol of Rome's good faith, as well as an acknowledgement of the sovereignty compromised in treaties. The fetial would then anoint a second priest, the pater patratus, who recited in a religiously prescribed "metrical formula" the text of the treaty. ${ }^{105}$ Next, he would swear to the absence of any fraud and implore Jupiter to smite the Roman people if first they violated the treaty. A white pig would be then be sacrificed, both as an offering to the gods and as a graphic demonstration of the divine wrath to be incurred by treaty-breakers. $^{106}$

Vattel himself recounted the fetials' rituals in seeking redress from an offending people and later, if Rome's demands were unsatisfied, in declaring war. ${ }^{107}$ The pater patratus again ventured into the foreign territory. Having draped his head in a garment of wool, he came to the border, where he solemnly proclaimed Rome's complaint and called upon Jupiter to witness the injury. ${ }^{108}$ Crossing the boundary line, he recited the charge again, an act that he would repeat when he first encountered a citizen of the offending people, when he entered the city gates, and when he came into the marketplace. ${ }^{109}$ If after thirty-three days no just reparation had been made, the fetial would return to Rome, where the Senate would deliberate and vote to declare war. ${ }^{110}$ Accompanied by at least three men, the fetial then traveled once more to the border, and, having formally announced a state of war, he cast a cornet-wood spear into the foreign territory. ${ }^{111}$

tilius (673-642 B.C.). See LIVY, supra note 81, at 1.32.4-5.

104. See Livy, supra note 81, at 1.24; Pliny the Elder, NATURAlis Historiae 22.3.5 (W.H.S. Jones trans., Harvard Univ. Press 1951) (77 A.D.). Pliny adds that the verbenarius carried this same bit of turf from the citadel when he accompanied his priestly brothers in order to perform a formal declaration of war, or clarigatio. See id. Occasionally, this vegetation is described simply as "tufts." See LIVY, supra note 81, at 30.43.9.

105. LIVY, supra note 81, at 1.24.

106. See id. Livy recounts all of these elements in splendid detail in his chronicle of the legendary story of the Horatii and Curiatii, two sets of triplets chosen from the Roman and Alban forces, respectively, to fight to the death. In this way, each army lost no more than three men in the contest. See id. at 1.24-25.

107. See VATTEL, supra note 27 , at 315 .

108. See LIVY, supra note 81, at 1.32.6-8.

109. See id.

110. See id.

111. See id. 
By these elaborate means, Rome exhibited good faith even in the commencement of hostilities. She also took steps to ensure the approbation of the gods. When the distance between Rome and her enemies later precluded these fetial missions, the ritual was preserved by nominating as "enemy soil" a section of ground in the Circus Flaminius. ${ }^{12}$ Octavian (later Augustus Caesar), himself a fetial, hurled a spear into this same spot of earth when Rome determined to subdue Cleopatra, Queen of Egypt. ${ }^{113}$

3. The Policing of Fides. Beyond the purview of the fetials and their ancient code, the sanctity of oaths found equally powerful expression in Rome's other interaction with her enemies and her allies. Since the conduct of warfare in Rome was explicitly governed by "humane laws ... under all the guarantees of religion," only wars that conformed to these rules could be deemed just. ${ }^{114}$ As discussed above, a violation of a treaty or of a similar pledge of faith provided ample justification. Roman soldiers riding into battle often invoked the god in whose name a perjured oath had been sworn. ${ }^{115}$ Augustus, it is said, sometimes compelled foreign peoples who sued for peace to pledge their good faith in the temple of Mars Ultor ("Mars the Avenger"). ${ }^{116}$ The grave symbolism of such a gesture was surely unmistakable to those who once gave their word to a Roman.

So assiduously was the nomen Romanum guarded that Romans who misused allied citizens could be executed in the name of restoring faith. In 271 B.C., some three hundred men were summarily "scourged and beheaded" in the Forum Romanum as an admonition to Romans and an example to the world. ${ }^{117}$ These troops had entered the city of Rhegium under pretense of liberating it from enemy Campanian troops. Once in possession of the city, however, they proceeded to massacre or to expel the citizens in order to enjoy its bounty themselves. ${ }^{118}$ Rome would not brook such perfidy. Ever circumspect, the Romans punished offenders known to them and re-

112. See GOAR, supra note 98, at 9-10.

113. See id. at 10 n.15.

114. CICERO, DE OFFICIIS, supra note 1, at 1.11.36.

115. See LIVY, supra note 81, at 6.29.2 (describing the Roman assault on the Praenestini in 380 B.C.).

116. See 2 Roman CiviLization 42-43 (Naphtali Lewis \& Meyer Reinhold eds., 1955) (offering an adaptation of Suetonius' Life of Augustus 21, 23).

117. POLYBIUS, supra note 5, at 1.7. Livy reports that more than 4000 soldiers were beheaded. See LIVY, supra note 81, at 28.28.1-4.

118. See POLYBIUS, supra note 5, at 1.7. 
spectfully considered allegations brought from afar. In some instances, embassies from aggrieved cities received audience with the Roman Senate itself in order to pray for justice. ${ }^{119}$ When this occurred, not even the most powerful and noble Romans were immune to scrutiny and to possible punishment. ${ }^{120}$

4. Fides as a Justification for Dominion. An untiring devotion to Fides - be it preservation or atonement for breach-was central to the Roman conception of itself and of its well-being. In the mind of the ancients, Rome was not right because she was mighty. To the contrary, Rome's virtue was that which justified her dominion. Even St. Augustine, who dismissed the idea that fate alone had produced Rome's greatness, asseverated that God had deigned to bless the pagan enterprise because of the Romans' virtuous pursuit of honor. ${ }^{121}$ That is not to imply, however, that Romans were untouched by vice. Cicero deplored the fact that in his day the old models of republican virtue had become little more than "romantic inventions." 222 Vattel acknowledged Roman chicanery in the surrender and subsequent destruction of Carthage in 146 B.C. ${ }^{123}$ Nevertheless, Rome's general reverence for Fides led Romans to regard their good fortune as a sign of the gods' favor. In fact, "those who controlled [religion] claimed that their decisions were valid in heaven as on earth." 124 Ben Jonson's Renaissance drama Catiline contains a poignant expression of this perspective. When the Roman people cry out, "The Voice of Cato is the voice of Rome," Cato not-so-humbly counters that "the voice of Rome is the consent of heaven."

119. See, e.g., LIVY, supra note 81, at 29.16-18 (recording the address of the Locrians to the Roman Senate in 204 B.C.). In response to these alleged atrocities, the Senate dispatched to Locri a praetor, 10 senators, and others to conduct a thorough investigation. See id. at 29.20.

120. See id. (recording accusations brought against and an investigation of the famous general Publius Scipio (later Africanus), who would defeat Hannibal in the Second Punic War).

121. See St. Augustine, De Civitate Dei 5.12.93-95 (William M. Green trans., Harvard Univ. Press 1963) (413-426 A.D.).

122. Cicero, In C. Verrem Actio II 3.78.182, in 2 The Verrine Orations 1, 225 (L.H.G. Greenwood trans., Harvard Univ. Press 1935) (speech delivered in 70 B.C.) ("I am not unaware, gentlemen, that ancient precedents are now listened to, and regarded, as romantic inventions, and I will confine myself to our own unhappily degenerate days.").

123. See VATTEL, supra note 27, at 269 (recounting how the Romans, having promised to preserve the freedom of Carthage, later claimed that the citizens, not the city itself, had been meant).

124. A.D. Nock, A Feature of Roman Religion, 32 Harv. TheOlogical Rev. 83, 93 (1939).

125. Ben Jonson, CATILINE act 3, sc. 1 (W.F. Bolton \& Jane F. Gardner eds., Univ. of Neb. Press 1973) (1611). 
Although this claim of a supernal imprimatur smacks of selfrighteousness and raises the troubling specter of both nationalism and imperialism, it may yet escape the condemning hand of postmodern criticism-especially if one looks beyond the sanctimonious rhetoric and the hegemony of Rome and embraces the dynamic natural law theory posited earlier in this Note. For if one confesses the inherent fallibility of human beings and their ability to perceive the divine, or natural, law, there remains a naked, honest optimism. A people's actions are in harmony with the natural law because of its enduring commitment to truth, not its perfect attainment thereof. No sovereign people may claim exclusive access to the law of nature, but every one of them can potentially speak with the commanding voice of rectitude. Virtue and principled action need not result in a posture of superiority; they must stem from and result in good faith. That is the essence of the natural law doctrine of Fides.

\section{B. Cicero and the Sanctity of Promise-Keeping}

Among the Romans of the late Republic, Marcus Tullius Cicero arguably proved the staunchest advocate of Fides, in all of its manifestations. As consul in 63 B.C., he had exposed and thwarted the internecine conspiracy of Lucius Catiline, ${ }^{126}$ thereby earning for himself the honorific title of pater patriae, father of his country. In word and deed, he became the champion of republican virtue, as well as of the natural law principle of faithfulness. It is his resounding voice that continues to counsel us across the centuries. In the estimation of Sir Ronald Syme, Cicero has exerted "an enduring influence upon the

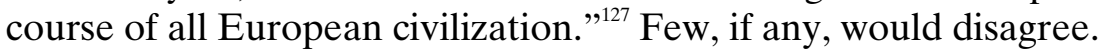

A successful politician, formidable orator, and prolific writer, Cicero has given us more insight into republican Rome and a more vibrant understanding of the republican spirit than any other figure of his time. He has introduced untold numbers of readers to the elegance of Latin prose, and he has provided historians with the clearest and most personal account of the demise of the Roman Republic, a tide of strife and bloodshed that would eventually claim his own

126. See HeICHELHEIM, supra note 3, at 204-06 (summarizing the events of the Catilinarian conspiracy). For a literary nod to Cicero's fortitude, see VERGIL, AENEID 8.666-69, at 248 (John Dryden trans., Heritage Press 1944) (original trans. 1697) (29-19 B.C.) (vividly describing the prophetic images from Roman history with which Vulcan decorated the shield of Rome's legendary founder, Aeneas: "Pains of the damn'd, and punish'd Catiline / Hung on a rock - the traitor; and, around, / The Furies hissing from the nether ground.").

127. Ronald Syme, The Roman Revolution 4 (Oxford Paperbacks 1960) (1939). 
life. ${ }^{128}$ In Plutarch's Life of Cicero, we hear him tersely described as "'a learned man and a lover of his country." "129 Even if these words of praise, attributed to Augustus Caesar, be apocryphal, they are most befitting such a man of faith-a man committed to the exposition of the natural law and to both the idealization and publication of Regulus' fidelity to the promise.

1. Cicero and the Natural Law. In the law, in particular, Cicero has guided the thinking of scholars in every age. One need not look far for proof. The natural law theorist Vattel opens his eighteenthcentury treatise with an inscription from Cicero's Somnium Scipionis: "For nothing of all that is done on earth is more pleasing to that supreme God who rules the whole universe than the assemblies and gatherings of men associated in justice, which are called States." Vattel also quotes Cicero liberally throughout his manuscript-some six times in a single chapter. ${ }^{131}$ Although it is now sadly misunderstood, Cicero's remark about the universality of the natural law crops up in American court opinions even now. Cicero foretold that "there will not be different laws at Rome and at Athens, or different laws now and in the future, but one eternal and unchangeable law will be valid for all nations and all times." ${ }^{132}$

According to Cicero, the natural law, fully harmonized both with nature and with the divine will, comprises a nearly ineluctable responsibility to abide by oaths. Herein lies the basis for the doctrine of promise-keeping outlined above in Section I.C. Cicero maintained that an oath "is an assurance backed by religious sanctity; and a sol-

128. For the most moving account of Cicero's proscription and assassination, see Plutarch, Cicero, in Fall of the Roman Republic: Six Lives 277, 317-20 (Rex Warner trans., Penguin Books 1958) (ca. 50-120 A.D.).

129. See id. at 319-20 (quoting the reassuring words of Augustus Caesar, who had discovered his grandson reading Cicero, a man assassinated with at least the complicity of Augustus).

130. VATTEL, supra note 27, at i ("Nihil est enim illi principi Deo qui omnem hunc mundum regit, quod quidem in terris fiat, acceptiu[s], quam concilia coetusque hominum jure sociati, quae civitates appellantur."); accord CICERO, De Re Publica, supra note 37, at 6.13.

131. See VATTEL, supra note 27, at 244-74 (containing Book 2, Chapter 17, entitled Of the Interpretation of Treaties).

132. CiCERO, De Re Publica, supra note 37, at 3.22. Some American judges have now reduced this declaration to a pedestrian observation about the desirability of uniform regulations. See, e.g., In re Data Access Sys. Sec. Litig., 843 F.2d 1537, 1549 (3d Cir. 1988) (offering Cicero's words to justify a "uniform federal statute of limitations" in securities cases). This interpretation is particularly vexed because of the Romans' strong commitment to permitting peoples under their control to maintain local customs, including peculiarities of law. See, e.g., KARL CHRIST, THE ROMANS 131 (Christopher Holme trans., 1984) (noting that "it was characteristic that [native] obligations at private law to non-Roman legal communities were all recognised"). 
emn promise given, as before God as one's witness, is to be sacredly kept. ${ }^{, 133}$ Failure to do so constitutes both perjury and injustice, and Cicero admits of few exceptions either to justify or to palliate the nonperformance of a sworn obligation. No duty of Fides is owed to a tyrant, ${ }^{134}$ for instance, and legitimate, binding promises may be abandoned to preserve the life or health of the promisor, or to protect the promisee if changing circumstances make fulfillment of the promise detrimental to his fundamental interests. ${ }^{135}$ Additionally, Cicero recognizes that oaths secured by force or criminal fraud are generally unenforceable. ${ }^{136}$

However, a distinction critical to this discussion is that none of the promises for which Cicero proffers these exceptions pertains to an oath properly sworn by a Roman, or Romans, to another sovereign people. As I have argued, these promises attain to a far higher level of respect and of ethical and legal scrutiny because they implicate not the honor of a single Roman, but that of an entire people. The fetial code and the elaborate rituals accompanying such oaths attest to their privileged status in Roman politics and religion. For these promises, there appear to be few, if any, just causes for failure to execute dutifully. Cicero confirms this point when he declares that "if under stress of circumstances individuals have made any promise to the enemy, they are bound to keep their word even then."

Cicero offered this dictum while explicating and defending the actions of Marcus Atilius Regulus. Reverting now to the legend itself, we shall encounter a fecund tradition, both literary and artistic, both ancient and modern. Nearly uniform in their tribute to and lionization of Regulus, the writers and painters who have transmitted this story recognize Regulus as the ultimate model of Fides in relation to another sovereign people. Consequently, they also demonstrate the place of honor given to this settled principle of natural law. These are the voices of the natural law dialogue. Finally, inasmuch as Cicero's analysis of the duty of Fides - and his rejoinder to Regulus' criticswill reveal the salience and vitality of this principle among the Romans, later interpretations of the story will assist us in

133. Cicero, De OfFICIIS, supra note 1, at 3.29.104.

134. See id. at 3.6.32.

135. See id. at 3.24 .92 (giving hypothetical examples of a dying man who has promised not to take a particular life-saving medicine and of a promise that would result in the death of the promisee if fulfilled).

136. See id.

137. Id. at 1.13.39. 
later interpretations of the story will assist us in comprehending both the appeal and the significance of Regulus' sacrifice in our own time.

2. The Story of Marcus Atilius Regulus. Within the Roman canon of exempla, none better illustrates faithfulness to promises made to other peoples than the heroic sacrifice of Regulus. ${ }^{138}$ Like so many of the Roman commanders who took part in the Punic Wars, he typified Roman ingenuity, courage, and virtue; he helped to define Roman-ness. Nevertheless, that fact alone does not explain fully why this story, in particular, has so captured our imagination. There is something more compelling in the nature of Regulus' conduct, something that speaks to our own sense of honor and justice. In turning to Regulus, we are compelled to confront the powerful bond both between the individual and society and between sovereign peoples. Thus, in Regulus, there is an unsurpassed greatness of spirit and a most comprehensive illustration of Fides. These are the qualities that John Milton extolled as "Worthy of Memorial."139

Although the veracity of Regulus' embassy to Rome has been disputed ${ }^{140}$ this is the version that has been accepted and passed down for centuries. Having sworn to the Carthaginians that he would return to them if the Roman Senate declined their request for an exchange of prisoners, Regulus sailed to Italy with a single, fixed purpose: to persuade the Senate to reject the Carthaginian overture. ${ }^{141}$ Although

138. For a summary of the story, see supra notes 3-10 and accompanying text.

139. John Milton, Paradise Regained 2.443-46, in Complete Poems And Major Prose 470, 504 (Merritt Y. Hughes ed., Odyssey Press 1957) (1671) (recognizing the contributions of Regulus).

140. See Tenney Frank, Two Historical Themes in Roman Literature, 21 ClASSICAL PHILOLOGY 311 passim (1926) (assessing the various versions of the tale and arguing for the historical truth of Regulus' mission to Rome).

141. The ancient sources are silent about the actual words uttered by Regulus in his promise to the Carthaginians. However, in the context of ancient warfare and negotiations of this kind, it was extremely common for the enemy to dispatch a captured senior officer or nobleman to his homeland to communicate terms of peace, a desire for an exchange of prisoners, and so forth. See infra notes 166-68 and accompanying text (providing other examples of this practice). In short, these missions were wagers - that is, the Carthaginians were betting on (1) Regulus' and the Romans' respect for Fides, (2) the Romans' unwillingness to refuse their request and thus to send Regulus, a Roman hero, to his death, and (3) Regulus' self-interest in remaining alive. As demonstrated by the public outcry incited by Regulus' plea to be remitted to the enemy, the Carthaginians had good reason to accept such a wager. In all likelihood, no other Roman prisoner, by means of his predicament alone, would have held such sway over the Senate and people of Rome. Regulus, on the other hand, was little more than a pawn, whose bond was the pledge of his life. Thus, under the express terms of the agreement, he was given a chance at life-no more, no less, and that probably under coercion—in exchange for Carthage's chance to seek release of its captive soldiers. If the Senate refused Carthage's request for an exchange of 
success would mean almost certain death, his speech before that revered body was both commanding and moving. Silius Italicus reports that when Regulus entered the chamber he immediately invoked the past perfidy of the enemy as grounds for denial: "Foil their knavish tricks, and teach a nation that delights in deceit how much, though I be a prisoner, is still left to Rome .... I would rather go down to the house of Hades than see the Romans strike so base a bargain." ${ }^{142}$ The Romans believed in abiding by oaths properly sworn to an enemy, but they knew how to punish those who failed to reciprocate. With regard to his own fate, Regulus held up his honor as a Roman citizen. Duty to his promise required that he leave Rome; leaving Rome was that which brought him closer to her: "My body is a Carthaginian chattel, but my spirit is yours. The former has been alienated from you, but the latter nobody has the power to make anything else than Roman." ${ }^{143}$

The bitter events concluding Regulus' life are fully recounted in both art and literature. In this concinnity of words and images, one discovers both the beauty and the inspirational force of the Regulus legend. Jacques-Augustin Pajou's Le Départ de Régulus pour Carthage $(1793)^{144}$ depicts Regulus' farewell to his family and to the Romans who adored him. As his grieving wife and small children reach out to him in desperation, even as they are restrained by those who would take him away, one hears the description of the scene given by Silius Italicus: "The Roman populace accompanied the senators, beating their breasts and mourning, till the vast Field of Mars was

prisoners, Regulus would return to die at Carthage-even if he had zealously advocated the Carthaginian cause; conversely, if the Senate agreed, Regulus would remain free in Romeeven if he had denounced the enemy's proposal. No consideration was ever given for his advocacy, but merely for his presence and his communication of a message. His promise to return - the consideration given by him-only strengthened the Carthaginians' position and guaranteed a return to the status quo ante if, as it turned out, the Senate declined the request. Therefore, if we were to view Regulus' agreement with the Carthaginians as a contract in the modern sense-against which, as I shall argue, the sacred nature of such promises militates, see infra notes 169-70 and accompanying text-it would be mistaken as a matter of ancient practice to infer any implied term in that contract whereby Regulus was obliged to plead the Carthaginians' case.

142. Silius Italicus, Punica 6.482-89 (J.D. Duff trans., Harvard Univ. Press 1934) (ca. 88-96 A.D.).

143. Zonaras, EPITOME of Histories 8.15, quoted in 1 Dio Cassius, Roman History 445 (Earnest Cary trans., Harvard Univ. Press 1914) (attempting to reconstruct lost or incomplete chapters of Dio's third-century A.D. text, which was epitomized by Zonaras) (ca. 1143 A.D.).

144. See 2 Pierre Rosenberg et al., Catalogue Illustré des Peintures: École FrANÇAISE, XVIIe ET XVIIIe SIÈCles 30 (plate 611) (1974) (cataloguing Pajou's Le Départ de Régulus pour Carthage (1793) among the Louvre's collection of French paintings). 
filled with the sound." ${ }^{145}$ To know what must have been going through Regulus' mind and heart, to contemplate such steely resolve and such an unwavering commitment to honor, one need only turn to the Regulus of impressionist J.M.W. Turner (1828). ${ }^{146}$ While pondering the misty harbor of Rome and a ship readying to sail, one is caught in that critical moment, from which Regulus can never turn back. Horace's words echo in the ears: "Full well he knew what the barbarian torturer was making ready for him; and yet he pushed aside the Roman kinsmen who blocked his path ... with no less unconcern than if some case in court had been decided, and he were leaving the tedious business of his clients ...." ${ }^{, 147}$ Finally, there is Salvator Rosa's The Death of Marcus Atilius Regulus (1652). ${ }^{148}$ In Rosa's shared vision, vengeful Carthaginians hammer spikes into a large wooden barrel. Confined in this instrument of torture, Regulus suffered as only the inimitable Seneca can express: "Nails pierce his skin, and wherever he rests his wearied body he lies upon a wound; his eyes are stark in eternal sleeplessness." ${ }^{149}$ With this pitiable sight, the story of noble Regulus concludes.

3. Cicero's Defense of Regulus' Sacrifice. As illustrated above, numerous versions of the tale are to be found in the ancient sources. ${ }^{150}$ However, that offered by Cicero in the De Officiis ${ }^{151}$ may be both the best known and the most passionate in its defense of Regulus' conduct: "From the many splendid examples in history ... we could not easily point to one either more praiseworthy or more heroic than the conduct of Regulus." ${ }^{, 152}$ Cicero composed the De Offi-

145. SiliUs ITALICUS, supra note 142, at 6.494-95 (footnote omitted).

146. See KathleEn Nicholson, TuRner's Classical LANDSCAPES: Myth AND MEANING 112 (1990) (plate 50) (showing Turner's Regulus (1828; reworked in 1837), held by the Tate Gallery, London). Turner also composed a poem honoring Regulus. What it may lack in stylistic refinement it more than recovers in the power of its sentiment: "Not wife nor children dear, or self, could hold / A moment's parley, _ love made him bold.” Turner Bequest 123 (Turner Sketchbooks), Devonshire Coast No. 1 (1811), reprinted in NiCHOLSON, supra, at 139 n. 48 .

147. HORACE, supra note 79, at 3.5.49-54.

148. See NiCHOLSON, supra note 146, at 113 (plate 51) (1990) (featuring a photograph of Rosa's The Death of Marcus Atilius Regulus (1652), on display in the Virginia Museum of Fine Arts, Richmond).

149. SeneCA, De Providentia 3.9, in 1 Moral Essays 2, 21 (John W. Basore trans., Harvard Univ. Press 1928) (attributed to the latter part of the author's life: no later than 65 A.D.).

150. See Dio CASsius, supra note 143, at 11.19-31; Diodorus Siculus, Library OF

History 23.12-16 (Francis R. Walton trans., Harvard Univ. Press 1957) (ca. 60-30 B.C.).

151. See CiCERO, DE OfFICIIS, supra note 1, at 3.26.99 to 3.32.115.

152. Id. at 3.30.110. 
ciis, or On Duties, as a handbook for his son on the fine art of being a noble Roman. ${ }^{153}$ As he imparts to young Cicero, "[j] ustice is ... in every way to be cultivated and maintained, both for its own sake (for otherwise it would not be justice) and for the enhancement of personal honor and glory." ${ }^{154}$ This is the key to Cicero's philosophy, and it reflects both the manner in which he lived and the path he had envisioned for his son.

When Cicero sets forth Regulus as a model of behavior, he methodically anticipates and dismantles each of the arguments raised by Regulus' detractors. First, Regulus did not abide by his oath from fear of divine wrath: "[I]t is the universally accepted view of all philosophers that God is never angry, never hurtful." 155 Furthermore, even if a violation of Regulus' promise would have angered great Jupiter, what more horrible punishment might the god have inflicted than the torture devised by the Carthaginians? $?^{156}$ Second, Regulus did not fail to abide by the esteemed principle of the lesser of two evils. ${ }^{157}$ Although Regulus' life was of inestimable value to himself, to his family, and to a people embroiled in war, there is no evil greater than moral wrong. ${ }^{158}$ Perjuring himself would have constituted such a crime. ${ }^{159}$ Third, the fact that Regulus' oath had been given by a captive to an enemy-perhaps even coerced-is of no consequence, since force could not have prevailed against a man of Regulus' mettle. ${ }^{160}$

The last and most intriguing objection focuses on the issue of expedience. According to Cicero, Regulus could in no wise have been released from his obligation by reason of expediency, for "nothing can be expedient which is not at the same time morally right; neither can a thing be morally right just because it is expedient, but it is expedient because it is morally right." 161 Elsewhere he adds that "[p]eople overturn the fundamental principles established by Nature,

153. See id. at 3.33.121 (ending the treatise by reminding young Cicero of the educational purpose of the text: "Farewell, my dear Cicero, and be assured that, while you are the object of my deepest affection, you will be dearer still to me, if you find pleasure in such counsel and instruction.").

154. Id. at 2.12.42.

155. Id. at 3.28.102.

156. See id.

157. See id. at 3.29.105.

158. See id.

159. See id. at 3.29.108.

160. See id. at 3.30.110.

161. Id. 
when they divorce expediency from moral rectitude."162 He recognizes a similar union between justice and utility. ${ }^{163}$ Consequently, Regulus' decision, in its moral correctness and justness, must also be deemed the only truly expedient and useful course of action. Ethicist Martin Hollis would go even further, arguing that this heroic act was not only brave but rational. ${ }^{164} \mathrm{He}$ concludes with a defense of Cicero himself: "Cicero refused to be puzzled by actors who chose what it was expedient to do by deciding what was morally right. He has my support." 165

In fitting republican style, Cicero continues his tribute to Regulus by invoking the mos maiorum. He sought to convince his son not only of the rightness of Regulus' deeds but also of their Roman-ness. Rome's noble ancestors had exhibited a strictness and an unflinching discipline in their fidelity to promises, even those made by individual citizens. Properly speaking, Regulus' oath was a sponsio, a vow sworn to a foreign people by a single Roman representative. While the promise was binding on the promisor, the Roman Senate had the discretionary power to approve or to reject the terms of the underlying proposal. Cicero cites two examples from Roman history in which citizens who had made similar pledges were handed over to the enemy. On one occasion, the two consuls captured at the battle of the Caudine Forks made peace with the victorious Samnites. When the Roman Senate declined the terms of that peace, the consuls were returned to the enemy. ${ }^{166}$ In another episode quite similar to that of Regulus, ten Romans taken by Hannibal at the battle of Cannae were sent to Rome to negotiate for an exchange of prisoners. ${ }^{167}$ Like Regulus, they were sworn to return to Hannibal if they failed in their mission. When the Senate again refused, the one prisoner who attempted to remain at Rome was carried back to the Carthaginians in chains. ${ }^{168}$

Given the fact that sponsiones were not treaties, but rather pledges made by individuals, one might be tempted to regard them as contracts. ${ }^{169}$ Nevertheless, reducing Regulus' fidelity to that of a con-

162. Id. at 3.28.101.

163. See CiCERO, De Legibus, supra note 28, at 2.4.8.

164. See MARTIN Hollis, Reasons of Honour, in REASON IN ACTION 263, $280-81$ (1996).

165. Id. at 281.

166. See CICERO, DE OFFICIIS, supra note 1, at 3.30.109.

167. See id. at 3.32.113.

168. See id.

169. See, e.g., Charles Fried, The Rise and Fall of Freedom of Contract. By P.S. Atiyah, 93 
tractual promise is as lamentable-even ludicrous-as citing Cicero's definition of natural law to justify uniform securities laws. ${ }^{170}$ This interpretation properly notes an important distinction between the sponsio and the treaty, but it ignores the continued presence of a sovereign people as the second party to that promise. Were it not for his status as a Roman citizen, Regulus would never have gone to war, he would never have encountered this foreign people, and he would never have pledged a whit to the Carthaginians. In this context, his individual honor became inseparable from Roman honor. Even though Rome risked no breach of faith directly, any faithlessness towards the Carthaginians would have redounded to the reputation of Rome, the nomen Romanum.

Rome's extension of the doctrine of Fides to promises of this kind accentuates both her fervent respect for good faith towards other peoples and her keen sense of collective honor. The latter generally inheres in patriotism, but here it also highlights a peculiarly Roman conviction about the desirability of a commonality of interests among the citizenry. Cicero avers, "This, then, ought to be the chief end of all men, to make the interest of each individual and of the whole body politic identical. For, if the individual appropriates to selfish ends what should be devoted to the common good, all human fellowship will be destroyed." ${ }^{171}$ In the case of Regulus, the common interest was the nomen Romanum, and Regulus was never free to appropriate his own life for a purpose contrary to the preservation of that name. St. Augustine reiterates this ideal when he asks, "Then what tortures are there that should not be disregarded, while we keep faith with that country to whose blessedness faith itself leads?"

As a final matter, one must consider the ancients' assessment of the quality of Regulus' life. In short, was he blessed or cursed? The analysis of Cicero's exposition of the story directs us to the answer. Indeed both Cicero and the Stoic Seneca would have responded with consternation and incredulity to the pious theologian Boethius, who held up Regulus not as an exemplar of nobility, but as a warning about the vicissitudes of fortune. ${ }^{173}$ Selecting bons vivants from their

\footnotetext{
HARV. L. REV. 1858, 1864-65 (1980) (book review) (using Regulus as an example of fidelity to contractual promises).

170. See supra note 132 .

171. CiCERO, DE OFFICIIS, supra note 1, at 3.6.26.

172. ST. Augustine, supra note 121, at 5.18.100.

173. See Boethius, De Consolatione Philosophiae 2.6.35-40, in TheOlogical Tractates AND Consolation of Philosophy 130, 211 (H.F. Stewart et al. trans., Harvard Univ. Press
} 
respective milieus, Cicero and Seneca both advert to the comparative vacuousness of the life of leisure and security. For Cicero, "Virtue proclaims that [Regulus]... was happier while tormented with sleeplessness and hunger than Thorius carousing on his couch of roses"; ${ }^{174}$ to Seneca, “"[n]o man . . seems . . . more unhappy than one who has never met with adversity.' For such a man has never had an opportunity to test himself." ${ }^{175}$ Fate had smiled on Regulus by enabling him to prove who he was in the most extraordinary fashion, as well as to authenticate what it meant to be Roman. Carlin Barton has labeled this struggle "the agon, the contest when truth was not so much revealed as created, realized, willed in the most intense and visceral way, the truth of one's being, the truth of being."176 Seneca imagines that no Roman worth his salt would prefer a life of ease to this glorious victory over fortune. ${ }^{177}$

4. Decoding Regulus. Admittedly, the heroism of Regulus may seem implausible, unattainable, or wholly undesirable to the modern mind. Few people ever find themselves in such momentous circumstances; fewer still may rise to the occasion. In the sixteenth century, Michel de Montaigne probed his own soul for answers to these fundamental questions. Taking up Regulus in three of the Essays-to illustrate the frugality of the Romans, ${ }^{178}$ to recommend nobler alternatives to suicide, ${ }^{179}$ and to wrestle with the burdens of greatness ${ }^{180}$ Montaigne returned to Cicero and Seneca's comparative analysis of the life best lived:

1918) (ca. 524 A.D.) ("Regulus had laid fetters upon many Africans taken in war, but ere long he found his own hands environed with his conqueror's chains.").

174. Cicero, De Finibus 2.20.65 (H. Rackham trans., Harvard Univ. Press 2d ed. 1931) (45-44 B.C.).

175. SENECA, supra note 149, at 3.3 (citing with approval a saying of "our friend" Demetrius, a Cynic philosopher).

176. Barton, supra note 75 , at 16 .

177. See SENECA, supra note 149, at 3.10-11 ("Surely the human race has not come so completely under the sway of vice as to cause doubt whether, if Fate should give the choice, more men would rather be born a Regulus than a Maecenas ....").

178. See Michel de Montaigne, Of the Parsimony of the Ancients, in The Complete Essays of Montaigne 224, 224 (Donald M. Frame trans., Stanford Univ. Press 1958) (1588) [hereinafter COMPLETE ESSAYS].

179. See Michel De Montaigne, A Custom of the Island of Cea, in Complete Essays, supra note 178 , at $251,254$.

180. See Michel De Montaigne, Of the Disadvantage of Greatness, in COMPlete EsSAYS, supra note 178, at 699, 700. 
I would certainly say what Cicero says, if I could speak as well as he. But if I had to apply their lives to mine, I would also say that the first [a man of leisure] is as much according to my reach ... as the second [Regulus] is far beyond it; that I can attain the latter only by veneration, but that I could readily attain the other in practice. ${ }^{181}$

As we admire the author's honest self-awareness, most of us would probably echo his sentiment with respect to our own lives.

That is not the end of the inquiry, however. Even if fidelity at such cost be purely aspirational for the majority, the rightfulness of Regulus' conduct is never at issue. Fortunately, we are not abandoned to our own shortcomings and human frailties: Regulus emerges as a beacon, guiding all of us to that knowledge of and commitment to Fides. François Vallançon believes that to encounter and to discuss Regulus encourages the discovery of the Regulus within each of us. ${ }^{182}$ Not only does he instruct us in the faithful observance of oaths, but on a more abstract level he may also guide us to discover our own vocation, our direction of faith. "Indeed when one speaks to Regulus, when one speaks of Regulus, one speaks as Regulus. One imitates him." ${ }^{184}$ Consequently, we may not need to make the sacrifice after all. Joseph Campbell would regard this as the role of the hero:

$[W]$ e have not even to risk the adventure alone, for the heroes of all time have gone before us. The labyrinth is thoroughly known. We have only to follow the thread of the hero path.... Where we had thought to travel outward, we will come to the center of our own existence. And where we had thought to be alone, we will be with all the world. ${ }^{185}$

Underlying this vital process of self-discovery, as well as the individual and collective commitment to faith, there is a profound sensitivity to the citizens whose voices authorize promises made to other peoples and whose honor rests on their fulfillment. In speaking of treaties, Welsh poet Dylan Thomas recognized the import and power of the promise: "Great is the hand that holds dominion over / Man by

181. Id. at 700 (footnote omitted).

182. See François Vallançon, Images romaines de morale et de droit: devotio et fides [Roman Images of Morality and of Law: Devotion and Faith], 34 ARCHIVES DE PHILOSOPHIE DU DROIT 305, 329 (1989).

183. See id.

184. Id. ("Eh ! bien, quand on parle à Regulus, quand on parle de Regulus, on parle comme Regulus. On l'imite.").

185. Joseph CAMPBell, The Power OF MYTH 123 (Betty Sue Flowers ed., 1988). 
a scribbled name." ${ }^{186}$ Yet, theoretically, the treaties of today's democratic governments are not dire obligations imposed vertically by an indifferent monarch or tyrant, but rather promises made with the consent and on behalf of every citizen. ${ }^{187}$ There simply cannot be a promise between sovereign peoples without the implied participation of all the individuals on each side of that pledge. To ignore that truth is to remove the compulsion of Fides and the collective shame of its abuse. More importantly, it eliminates the salutary effects of collective honor. If Regulus' individual oath signifies anything, it is that the honor of a people not only secures fulfillment of an oath but also encourages the self-knowledge and self-actualization of a people.

Silius Italicus presaged that "[Regulus'] laurels will be green throughout the ages, as long as unstained Loyalty [Fides] keeps her seat in heaven and on earth, and will last as long as virtue's name is worshipped." ${ }^{188}$ In some small measure, this Note seeks to return $\mathrm{Fi}$ des to that seat of honor. When all is said and done-when we have grown jaded and cynical, when we have become weary of being right in the midst of rampant infidelity to oaths on the international plane-Regulus stands before us still.

\section{TRANSMISSION OF THE ROMAN IDEAL: THE UNITED STATES}

In reconsidering Regulus and the natural law doctrine of promise-keeping in the modern era, it is both instructive and necessary to explore the reception of this tradition in the United States. Ample evidence of the Founders' exposure and response to this legacy suggests that, in the early period of our history, much, if not all, of the material surveyed in Part II of this Note was both known to and espoused by early American leaders. However, as I have suggested, something happened along the way to derail the United States' emulation of the Roman doctrine of Fides. In this final part, I shall attempt both to chronicle some features of that departure and to offer a

\footnotetext{
186. Dylan Thomas, The Hand That Signed the Paper, in The Poems of Dylan Thomas 66, 66 (Daniel Jones ed., New Directions 1971) (1952).

187. Such an awareness surely inspired the provision of the Swiss Constitution permitting a national referendum on all treaties signed by that country. See Bundesverfassung, Constitution Fédérale, Costituzione Federale [Constitution] [BV, Cst., Cost. Fed.] art. 89 (Switz.). In English, article 89 reads in pertinent part: "Treaties with foreign powers concluded for an undetermined period or for more than fifteen years shall also be submitted to the people for acceptance or rejection on demand of 30,000 Swiss citizens entitled to vote, or of eight Cantons.” The Federal Constitution OF SwitZerland art. 89, at 100 (Christopher Hughes trans., 1954).

188. SiliUs ITALICUS, supra note 142, at 6.546-49.
} 
few representative examples of how Fides no longer occupies that seat of honor. To conclude, I shall return to the American participation at the Rome Conference as a momentous and telling illustration of what we have lost and of what we must do in order to reclaim that tradition of respect for promises.

\section{A. Fides and the Founders}

Only slightly more than a century ago, a classical education, based in the literature of Greco-Roman antiquity, still served as a powerful homogenizing force in the nations of Western Europe. For many centuries prior to that, Latin had been the lingua franca, bonding numerous peoples with a common academic, legal, and religious tongue and with a shared cultural inheritance. The Founding Fathers, many of whom were themselves educated in Europe, partook of that tradition. Carl Richard has declared that, "by supplying a common set of symbols, knowledge, and ideas, the classical canon facilitated discourse" in early America and was a "form of social conditioning ... [that] left many unable to imagine the teaching of virtue independent of the teaching of the classics." 189 Notably, their perspective, termed classical republicanism, also encompassed the Roman theory of a commonality of popular interests..$^{190}$ The natural law doctrine espoused by Cicero and the story of Regulus necessarily constituted a vital part of this political philosophy.

The historical record offers abundant evidence of the impact of Roman thought on the Founders. For instance, Thomas Jefferson, well trained in both Greek and Latin, communicated in a letter to his friends that he had just completed a review of Cicero's De Officiis and another of the orator's philosophical treatises, the Tusculan Disputations. ${ }^{191} \mathrm{He}$ and his peers repaired to the classics both in their formal studies and in their leisure. ${ }^{192}$ As demonstrated by an early American court case, even the Roman worship of Fides was not mere

189. CARl J. Richard, The Founders And the Classics 10 (1994).

190. See Nathan Alexander Sales, Note, Classical Republicanism and the Fifth Amendment's "Public Use" Requirement, 49 DUKE L.J. 339, 351-52 (1999); see also supra notes 171-72 and accompanying text (discussing the notion of commonality among the Romans).

191. See Thomas JefFerson, Letter to Wells and Lilly (Monticello, Apr. 1, 1818), in WRITINGS, supra note 36, at 1413, 1413.

192. For a discussion of the classical training of other Founding Fathers, see RICHARD, supra note 189, at 24-38 (considering the education of Thomas Jefferson, Alexander Hamilton, John Adams, James Madison, and others). 
esoterica, but a meaningful concept to be applied in judicial reasoning. ${ }^{193}$

Wherever one turns, there are both direct and indirect transmissions of natural law theory and its privileging of the promise. In addition to William Blackstone, who incorporated a remarkably Ciceronian definition of natural law in his Commentaries on the Laws of England ${ }^{194}$ Emerich de Vattel kept Cicero's teachings at the forefront of the political and philosophical debates leading to the creation of the United States and its Constitution. ${ }^{195}$ In correspondence with the publisher of the English edition of Vattel, Benjamin Franklin reported, "[The text] has been continually in the hands of the members of our Congress now sitting, who ... have entertained a high and just esteem for [its] author." Vattel significantly influenced the Constitution. ${ }^{197}$ It is in this light that we should regard Article I, which grants Congress the power to "define and punish... Offences against the Law of Nations," Article VI, which declares that "Treaties... shall be the supreme Law of the Land." 199

Finally, the Founders also embraced the sacred nature of promises between sovereign peoples. In defending Vattel against a charge that he had eviscerated the doctrine of good faith, Jefferson stated unequivocally that, when contemplating the natural law, one "will never read there the permission to annul his obligations for a time, or for ever [sic], whenever they become 'dangerous, useless, or disagreeable." ${ }^{200}$ In keeping with that principle, contemporary judicial opinions heralded the equality of the parties as the fundamental prin-

193. See Sturges v. Crowninshield, 17 U.S. (4 Wheat.) 122, 151 (1819) (discussing the function of Fides among the Romans).

194. See 1 William Blackstone, COMMENTARIES * 41 ("This law of nature, being co-eval with mankind and dictated by God himself, is of course superior in obligation to any other. It is binding over all the globe, in all countries, and at all times ....").

195. For Cicero's influence on Vattel, see supra notes 130-31 and accompanying text.

196. Letter of Benjamin Franklin to Dumas (Dec. 19, 1775), reprinted in 2 THE REVOlutionary DiPlomatic CORRESPONDENCE OF THE UNited STATES 64, 64 (Francis Wharton ed., Wash., Gov't Printing Office 1889). For a more thorough account of the influence of Vattel on the Founding Fathers, see Joel R. Paul, The Geopolitical Constitution: Executive Expediency and Executive Agreements, 86 CAL. L. REV. 671, 736 n.328 (1998).

197. See, e.g., Arthur M. Schlesinger, JR., The Imperial Presidency 85-86 (1973).

198. U.S. CONST. art. I, § 8, cl. 10.

199. Id. art. VI, cl. 2.

200. JefFerson, Opinion, supra note 36, at 423-24 (rebutting Alexander Hamilton's claim that the quoted phrase, lifted from Vattel, see VATTEL, supra note 27, at 212, cited valid justifications for abandoning political alliances). 
ciple in treaty interpretation, even when it proved disadvantageous to American interests. ${ }^{201}$ The famous case of The Schooner Charming Betsy mandated that courts explore every avenue to avoid an interpretation of a congressional statute that would conflict with a treaty in force. ${ }^{202}$ Furthermore-and perhaps more importantly-our forefathers acknowledged the citizens who stood behind those pledges, as well as the Roman conception of collective honor. John Jay affirmed that "the mala fides [bad faith] ... of one ... sovereign[] is imputable to his subjects, and so becomes their mala fides." ${ }^{203}$ For Congress or a court to break faith with another sovereign people would therefore sully the name and reputation of every American.

\section{B. The Forgotten Promise}

Given this inherited legacy of natural law and the sacred obligation of good faith, we must query, then, just where are we in this natural law dialogue? How faithfully do we make and keep promises? Have we kept faith with our forebears, or have we abjured their commitment to natural law and to Fides? Unfortunately, the United States' record appears to point to the latter, suggesting a near pathology of bad faith. Daniel Patrick Moynihan has opined that "[i]n the annals of forgetfulness there is nothing quite to compare with the fading from the American mind of the idea of the law of nations." ${ }^{204}$ As a consequence, the Offenses Clause has long lain dormant as a primary vehicle for congressional legislation, in favor of the more familiar Necessary and Proper Clause..$^{205}$

A similar fate has befallen the doctrine of Fides. Most telling, if only symbolically, is that the United States, for nearly thirty years, has omitted to ratify the foremost international instrument concerning the faithful execution of promises, the Vienna Convention on the

201. See Jones v. Walker, 13 F. Cas. 1059, 1069 (C.C. Va.; district and date not given) (No. 7507) (recording John Jay's quotation from Vattel: "'Everything that tends to the common advantage in conventions, or has a tendency to place the contracting powers on an equality, is favorable ...."”).

202. See Murray v. The Schooner Charming Betsy, 6 U.S. (2 Cranch) 64, 118 (1804) (“[A]n act of Congress ought never be construed to violate the law of nations if any other possible construction remains ...."). For a discussion of the Charming Betsy line of cases, see Levy, supra note 28 , at $2714-19$.

203. Jones, 13 F. Cas. at 1063.

204. MoYNiHAN, supra note 31, at 99.

205. See, e.g., Missouri v. Holland, 252 U.S. 416, 432 (1920) ("If the treaty is valid there can be no dispute about the validity of the [implementing] statute under Article I, $\S 8$, as a necessary and proper means to execute the powers of the Government."). 
Law of Treaties. ${ }^{206}$ One scholar has bluntly noted that "the Law of Nations, especially at the level of the superpowers, still appears to be as liable to self-interpretation and abuse as at the time of Grotius." In short, we may find an unsavory wisdom in the words of Shakespeare's buffoonish Pistol: "For oaths are straws, men's faiths are wafercakes, / And holdfast is the only dog, my duck . . . ."208

To be sure, it is neither my purpose nor my intention to suggest that the United States is the worst offender in this respect, nor even that we break faith as often as we uphold it. Nevertheless, it is important to recognize that a change has occurred in our basic understanding of Fides that is incompatible with the natural law doctrine of Cicero and with that favorably discussed in early American texts. In essence, there has been a gradual nosing out of the absolutist concept of good faith and a concomitant severance of political expedience and moral rectitude.

Some have traced the origins of this departure to a debate between Governour Morris and James Wilson during the drafting of the Constitution: "Morris was concerned that the 'law of nations' [mentioned in the Offenses Clause] would be too imprecise to constitute federal law, and [he] wanted to ensure that Congress had the power-and even the responsibility-to codify specific crimes." ${ }^{209}$ Consequently, Congress was granted the right "to define" offenses against the law of nations. ${ }^{210}$ Once the potential "vagueness" of the law of nations, as well as of the natural law, had been admitted, the window to self-interpretation was open. Daniel Patrick Moynihan attributes this decision to a penchant for legalism among some of those who helped to draft the Constitution, many of whom were lawyers. ${ }^{211}$

Although the demise of the law of nations proceeded by means of a gradual erosion, the case of The Paquete Habana ${ }^{212}$ in 1900 ap-

206. See supra note 65.

207. Georg Schwarzenberger, The Grotius Factor in International Law and Relations: A Functional Approach, in Hugo Grotius AND InTERNATIONAL RELATIONS 301, 310-11 (Hedley Bull et al. eds., 1990) (emphasis added).

208. William Shakespeare, Henry V act 2, sc. 3 (comment of Pistol), in The COMPLETE WORKS, supra note 77, at 488, 497 (1600).

209. Zephyr Rain Teachout, Note, Defining and Punishing Abroad: Constitutional Limits on the Extraterritorial Reach of the Offenses Clause, 48 DUKE L.J. 1305, 1320 (1998). For the record of the debate itself, see 2 JAMES MAdison, Debates IN THE FEDERAL CONVENTION OF 1787, at 563 (Gallard Hunt \& James Brown Scott eds., 1987).

210. See Teachout, supra note 209, at 1320; see also U.S. CONST. art. VI, cl. 2.

211. See Moynihan, supra note 31, at 20-21.

212. 175 U.S. 677 (1900). 
peared to end the dialogue and to settle the issue once and for all-at least, within American courts. ${ }^{213}$ In an apparent contradiction, the opinion recognized the place of international law within the American legal system, but then deprived it of all meaning by limiting its application to situations in which "there is no treaty and no controlling executive or legislative act or judicial decision." 214 Today in the United States, every treaty, pact, or other promise made to another country can be unilaterally rescinded by a subsequent act of Congress. This is commonly known as the "last in time rule." 215 Even though the Restatement (Third) of the Foreign Relations Law of the United States urges courts to avoid a construction of a congressional act that would invalidate a treaty, ${ }^{216}$ there is nothing compelling courts to do so. In short, the only thing restricting Congress and the courts from breaking faith with another sovereign people is their respect for Fides. The health of the doctrine thus takes on tremendous significance.

There are numerous examples of the departure of American legal procedure and doctrine-as well as examples of our conduct of foreign affairs-from the values espoused by Cicero. To name an early and most infamous example, one might recall the United States' relations with its indigenous populations. As early as 1881, Helen Hunt Jackson excoriated the United States for its perfidy in treaty negotiation and performance with respect to the Native American peoples. ${ }^{217}$ Quoting from Grotius, Vattel, and Cicero, ${ }^{218}$ she invoked the natural law doctrine of promise-keeping for support in con-

213. Tracing the United States government's history of treaty performance is a task far beyond the reach of this Note. Only such a study — and none is known to me-would be able to chart accurately the decline of respect for promises made to other sovereign peoples. Furthermore, since the power of the natural law doctrine has most often resided in the pressure brought to bear by its philosophical and moral rhetoric, one would also have the unenviable task of investigating not only specific breaches of promises but also the debate preceding, and the reaction to, such breaches to determine exactly when natural law arguments ceased to be regarded as potentially persuasive.

214. The Paquete Habana, 175 U.S. at 700.

215. See Reid v. Covert, 354 U.S. 1, 18 (1957) ("[A]n Act of Congress ... is on a full parity with a treaty, and that when a statute which is subsequent in time is inconsistent with a treaty, the statute to the extent of conflict renders the treaty null."); Whitney v. Robertson, 124 U.S. 190, 194 (1888) (affirming that, where a federal statute and a treaty are in conflict, "the one last in date will control the other").

216. See RESTATEMENT (THIRD) OF THE FOREIGN RELATIONS LAW OF THE UNITED STATES § 114 (1987) ("Where fairly possible, a United States statute is to be construed so as not to conflict with international law or with an international agreement of the United States.").

217. See JACKSON, supra note 70, passim.

218. See id. at 18-29. 
demning the treachery of her country: "[R]epeated violations of faith with the Indians thus convicts us, as a nation ... of having outraged the principles of justice ... and of having laid ourselves open to ... that more certain natural punishment which, sooner or later, as surely comes from evil-doing as harvests come from sown seed." ${ }^{219}$ As the title of her book declares, Jackson denounced the preceding one hundred years as $A$ Century of Dishonor.

Fortunately, most of the breaches of faith committed by the United States have been neither so monumental nor so tragic. Yet, the questions of honor, the current status of Fides, and the place of the promise in America at the turn of a new century remain to be answered. Although our breaches of faith may be less egregious, it likewise appears that our awareness of the duties and rights attending those pledges of faith has declined. Certainly, the American people, who generally have no right of action under breaches of their own treaties, ${ }^{220}$ have become lost in the promise. Where is the investment of personal honor? What is the basis for our collective honor vis-à-vis other nations? To delineate all of these conditions and the record of America's promise-keeping would far exceed the scope and purpose of this Note. Let it suffice to consider two further cases in point: one highlighting our diminished concern for good faith towards foreign citizens, the other summarizing a direct breach of Fides.

Just as there is most often no private right of action under treaty law for American citizens, there are also no individual consequences, no culpability for a breach thereof. Recently, in Breard v. Greene, ${ }^{221}$ a Paraguayan national who had been convicted of murder was refused a writ of habeas corpus ${ }^{222}$ and forthwith went to his death in a Virginia prison. Although the United States admitted that the Vienna Convention, now customary international law, had been violated, ${ }^{223}$ the failure of the accused to raise the treaty's guarantee of consular counsel at the state court proceedings resulted in a waiver of his treaty protections. ${ }^{224}$ Neither a pending judgment of the International Court

219. Id. at 29.

220. See Tel-Oren v. Libyan Arab Republic, 726 F.2d 774, 808 (D.C. Cir. 1984) (stating that there is no individual right of action under a treaty). However, where a treaty is self-executing, such a right of action might lie. See Smith v. Socialist People's Libyan Arab Jamahiriya, 886 F. Supp. 306, 310 (E.D.N.Y. 1995).

221. 523 U.S. 371 (1998).

222. See id. at 378-79.

223. See id. at 380 (Breyer, J., dissenting).

224. See id. at 375-76. 
of Justice in the Hague nor an unsuccessful claim filed by his native country sufficed to stay his execution. ${ }^{225}$ Under strict Roman notions of Fides, this outcome would have been unthinkable, for a people willing to execute their own citizens in order to restore good faith ${ }^{226}$ would have been loath to sacrifice that faith in the name of a procedural technicality. Under any conditions, such an outcome, as a violation of treaty obligations owed to the citizens of another sovereign people, is deplorable.

Then there was the blatant disregard for promises once held sacred. Witness Richard Holbrooke, the United States Ambassador to the United Nations, castigating Republicans in the House of Representatives for blocking payment of delinquent dues promised to that international body. ${ }^{227}$ Owing more than $\$ 1.5$ billion, the United States currently stands in peril of losing its vote in the United Nations General Assembly. ${ }^{228}$ If we recall the pronouncement of Jefferson, we are reminded that, in the absence of a matter of national security, a violation of an oath is not to be countenanced, even when the terms of that promise have become "dangerous, useless, or disagreeable." 229 The failure of the United States to remit these funds, which we have in surplus, hardly satisfies even the third, and weakest, of these circumstances. After all, is it disagreeable to maintain good faith with an international organization whose primary body we have the privilege of hosting and on whose powerful Security Council we hold a coveted seat? This sorry state of affairs not only constitutes perjury but also evinces what one commentator has called a "continued ... pattern of withdrawal that borders on xenophobia." ${ }^{230}$ These decisions not only deserve the chastisement of our treaty partners, but they also preclude our full participation in international discourse and thus in the natural law dialogue.

\section{See id. at 377-78.}

226. See supra notes 117-18 and accompanying text.

227. See Barbara Crossette, Holbrooke Accuses House of Hurting U.S. Role in the World, N.Y. TIMES, Oct. 27, 1999, at A12.

228. See Christopher S. Wren, U.S. Told It Must Pay $\$ 550$ Million or Risk Losing U.N. Vote, N.Y. TIMES, Oct. 6, 1999, at A14 (estimating the United States' total indebtedness to the United Nations and noting the minimum payment recently demanded by that body). 229. See supra note 200 and accompanying text.

230. Mortimer B. Zuckerman, Editorial, A Dangerous Abdication, U.S. NEws \& WORLD REP., Oct. 25, 1999, at 72. 


\section{Future Promise?}

At the Rome Conference for establishing the ICC, the United States again stood apart from the community of nations and refused to endorse the charter approved by the delegations of some 120 countries. ${ }^{231}$ As I noted in the Introduction, there is no breach of Fides in not pledging a nation's faith when that nation believes that it either cannot or will not abide by the terms of the proposed promise. However, the Rome Statute offers an intriguing wrinkle to this inquiry: as an agreement about the prosecution of breaches of earlier agreements, the decision to sign or not to sign further implicates the doctrine of good faith. Therefore, this inquiry begs not only a consideration of world reaction to our behavior in Rome and the specific objections of the United States, but also an analysis of these events as seen through the Roman lens of Fides. Despite the rather bleak conclusion compelled by the result of the Rome Conference, there are a number of positive voices and of encouraging acts that foretell a better day for promise-keeping.

1. The Rome Conference. As the most recent and significant diplomatic endeavor of the United States, the Rome Conference of 1998 raises new questions about our country's attitude regarding promises. If the number of foreign observers and newspapers inveighing against us for our performance in Rome be any indication, the misgivings outlined above may sadly be justified. During the course of the negotiations, in which our "nearest and dearest told [us] to get stuffed," ${ }^{232}$ the German press labeled the United States a Feindbild ("Image of the Enemy"). ${ }^{233}$ Others were even less charitable. In evaluating the response of America's allies, one commentator crowed that the "delegations who defied Washington's arm-twisting showed that although the United States may be the world's only remaining superpower, other countries increasingly see it as a microcephalic, over-muscled giant." ${ }^{234}$ The foreign ministers of both France and Germany lamented the American posture, ${ }^{235}$ and Kofi Annan,

231. See supra note 14.

232. Gwynne Dyer, World Court Second Blow for U.S., TORONTO STAR, July 24, 1998 (Metro ed.), available in 1998 WL 30716888.

233. See Katja Ridderbusch, UN-Konferenz für Weltstrafgerichtshof [UN-Conference for the World Criminal Court], DIE WeLt, July 18, 1998, at 6.

234. Ian Williams, Criminal Neglect, NATiON, Aug. 10, 1998, at 6.

235. See German Minister "A Bit Sad” About US Rejection of International Criminal Court, BBC Monitoring Europe-Political, July 19, 1998, available in LEXIS, News Library, BBC file 
Secretary General of the United Nations, openly criticized the United States' intransigence. ${ }^{236}$ Primarily, the United States objected to appointing an independent prosecutor, rather than vesting the United Nations Security Council with the authority to initiate investigations. ${ }^{237}$ Furthermore, there was a concern that American soldiers could be put on trial without the United States' approval. ${ }^{238}$

Indulging in a bit of conjecture, one may imagine the Roman reaction to this outcome. It is probable that a Roman observer of Cicero's ilk would have found nothing exceptional in the United States' unwillingness to sign the Rome Statute. Where no oaths bound Romans to behave in a certain way, they were free to act as they pleased-even barbarously by modern standards, so long as their conduct complied with the fetial code of just warfare. Yet, there is an irony here. The Rome Statute, in establishing a body to prosecute offenses such as war crimes and crimes against humanity, is in essence another treaty about treaties. That is, the prospective ICC is intended to punish only breaches of promises already made under the Geneva Conventions and other treaties.

In all likelihood, the Romans would have been flummoxed by the need for such a body in the first instance. There were no supranational bodies at the time of the Roman Republic; more to the point, under the Roman system of Fides, they would have been utterly unnecessary. As discussed earlier in this Note, no one could have been more harsh in the punishment of perfidious Romans than the Romans themselves. ${ }^{239}$ If they had signed agreements pertaining to war crimes and crimes against humanity, their respect for Fides would have demanded faithful performance; if their soldiers had violated those agreements, their honor would have necessitated a swift and merciless punishment. From this vantage point, the United States' hesitance to submit to the jurisdiction of the new court betrays a disturbing lack of regard for Fides, or at least a fear of its enforcement.

(reporting comments of German Foreign Minister Klaus Kinkel); Hubert Védrine, "Je souhaite que d'autres états se joignent aux 120 signataires" ["I wish that other states would join the 120 signatories"], LE MONDE, July 21, 1998, at 2 (publishing the statement of Hubert Védrine, French Minister of Foreign Affairs).

236. See Cour pénale internationale: Kofi Annan critique les États-Unis [International Criminal Court: Kofi Annan Criticizes the United States], LE Monde, July 15, 1998, at 3.

237. See Minh T. Vo, Washington's Worry: US Soldiers Put on Trial Abroad, Christian SCI. MONITOR, July 24, 1998, at 6.

238. See id.

239. See, e.g., supra notes 117-20 and accompanying text (recounting the execution of Romans who had committed atrocities in violation of Rome's pledges to an allied people). 
Closely linked to this discussion is a hypothetical served up by Martin Hollis. Having argued for the propriety and rationality of Regulus' behavior, he queries, "Would an American general, captured by the Vietcong and sent to Washington on the same terms [as Regulus], have been likely to keep his oath and return after sabotaging his mission? Do we believe that he should?"240 Indeed the resounding reply of most Americans would be absolutely not. Cicero, the dictates of Fides, and this American citizen would have to disagree.

2. The Path to Reclamation. The twentieth century has witnessed dramatic developments in international law and a prodigious increase in both the number and the functions of international legal instruments and juridical bodies. From the four Geneva Conventions to the war crimes tribunal for the former Yugoslavia, ${ }^{241}$ the world has moved towards greater cooperation in both defining and punishing infractions of international legal norms. International law is alive and well, and recent history portends its continued, earnest expansion. Even in the United States, the voices of international law appear to be growing in number and influence. In 1996, for example, Congress revived the Offenses Clause to enact the War Crimes Act; ${ }^{242}$ in the courts, there have been attempts to reintegrate international legal standards into the "'statutory regime",; ${ }^{243}$ and in other corners, legal scholars have proponed incorporation of ius cogens norms into the Ninth Amendment. ${ }^{244}$ Even Walter Cronkite has lent his support to this movement. At a recent banquet held at the United Nations by

240. HoLLIS, supra note 164, at 264.

241. See, e.g., Convention (No. I) for the Amelioration of the Condition of the Wounded and Sick in Armed Forces in the Field, Aug. 12, 1949, 6 U.S.T. 3114, 75 U.N.T.S. 31; United Nations Security Council Resolution 827 on Establishing an International Tribunal for the Prosecution of Persons Responsible for Serious Violations of International Humanitarian Law Committed in the Territory of the Former Yugoslavia Since 1991, S.C. Res. 827, U.N. SCOR, 48th Sess., 3217th mtg. at 29, U.N. Doc. S/Res/827 (1992), adopted unanimously May 25, 1993. One might also consider the establishment of the United Nations, see U.N. CHARTER; of the International Court of Justice, see Statute of the International Court of Justice, June 26, 1945, 59 Stat. 1031, T.S. No. 993; and of the European Court of Human Rights, see Convention for the Protection of Human Rights and Fundamental Freedoms, Nov. 4, 1950, arts. 38-56, 213 U.N.T.S. 221, 242-49.

242. See Teachout, supra note 209, at 1306-07 \& n.7 (discussing the use of the Offenses Clause to justify enactment of the War Crimes Act of 1996, as well as the Torture Victim Protection Act of 1991).

243. See Levy, supra note 28, at 2714-16 (stating that in Princz v. Federal Republic of Germany, 26 F.3d 1166 (D.C. Cir. 1994), Judge Patricia Wald sought to "advance the monist agenda to create "a statutory regime which incorporates standards recognized under international law" (quoting Princz, 26 F.3d at 1183 (Wald, J., dissenting))).

244. See id. at 2724. 
the World Federalist Organization, the retired journalist was honored with the Norman Cousins Global Governance Award. ${ }^{245}$ In his acceptance speech, he endorsed "a strengthened United Nations and a system of world governance in which international law would be respected and enforced." 246 Such progress would both require and further foster dutiful observance of the natural law doctrine of Fides.

Perhaps the most formidable obstacle to a reclamation of Fides is the statist orientation of contemporary international law and its definition of sovereignty. Although sovereignty is properly the basis for respecting an identifiable people and its right of self-determination, the principle is most often invoked by countries and leaders seeking to avoid the scrutiny, condemnation, and possible intervention of the international community. ${ }^{247}$ More often than not, that condemnation is also much deserved. Certainly, there is comfort and security behind that wall of legal fiction, a wall behind which the faces, the names, and the honor of persons-both individually and collectively-are nearly entirely obscured. Why not view international obligations as mere contracts? The standard of Fides is much lower, and, in case of breach, a country can take refuge behind its sovereignty. ${ }^{248}$ One must wonder, would it not be otherwise if members of the Senate Foreign Relations Committee, as modern-day fetials, had still to carry that clump of sod, perhaps taken from the Capitol lawn, to the shores of those with whom they made promises?

Although Webster's defines sovereign as "independent of all others," ${ }^{249}$ we must not forget that the etymology of the word reflects a qualitative aspect, rather than a geopolitical one; that is, from the Vulgar Latin superanus, sovereign also denotes excellence of character. "Sovereign" once communicated as much about the honor of a deserved status as it did about the status, or power, itself. The Romans of Cicero's day comprehended and lived that principle. Let it

245. See Newsmakers, Winston-SALEM J., Oct. 21, 1999, at A2. Walter Cronkite served as anchor of the CBS Evening News until 1981. See id.

246. Id.

247. Consider the example of former Chilean dictator Augusto Pinochet, who has attempted to raise sovereign immunity as a bar to his prosecution for torture. See Regina v. Bow Street Metro. Stipendiary Magistrate ex parte Pinochet Ugarte, [1998] 3 W.L.R. 1456 (H.L.) (denying Pinochet's sovereign immunity claim).

248. Sir Thomas More notes a perverse irony in the comparison of treaties to contracts. While countries somehow feel less obligated by treaties qua contracts, contractual promises are often observed far more faithfully than treaties ever were. See MORE, supra note 67, at 95-96. In fact, a deception between individual parties to a contract would elicit cries of "Sacrilege! They deserve the gallows!" Id. at 96 .

249. WEBSTER'S NEW WORLD DICTIONARY 1363 (2d college ed. 1986). 
never be said that a people's sovereignty is enhanced by abusing that concept to renege on or to weasel out of its obligations. For the United States to do so betrays the promise of our country, and it forever clouds the honor of our people. As former Chairman of the Senate Foreign Relations Committee J. William Fulbright said, "[i]t is of course reasonable to ask why we must take the lead .... [T] he answer is that we, being the most powerful of nations, can afford as no one else can to be magnanimous. ${ }^{250}$ We can afford the cost of Fides. What we compromise in independence and isolation we gain twofold in national honor, or true sovereignty. Independence and self-governance are purchased by might; sovereignty is achieved by honor.

\section{CONCLUSION}

"To teach mankind so effectively that the teacher ceases to be needed because the lessons have permanently affected men's fundamental convictions, is a very great achievement. ${ }^{251}$ Edith Hamilton so described the contributions of Cicero to generations of English schoolboys, who had learned how to be gentlemen even as they recited the orations and moral treatises of the Roman master. ${ }^{252}$ I should venture to guess that they had learned far more. They were engaged in the moral, ethical, and legal discourse with which Cicero had occupied himself; they were participants in the natural law dialogue that he had continued and fueled for centuries; they had met Marcus Atilius Regulus. If, as Velleius Paterculus predicted, "the race of man shall sooner pass from the world than the name of Cicero be forgotten," ${ }^{253}$ perchance the light of Regulus' fidelity will share in that reward and will guide promise-makers for all posterity.

For Americans today, far more is at stake than a return to traditional curricula. If we fail to recast the promise as an embodiment of good faith, we are at peril of losing not only the respect of the world but also that which helps to define who we are and thus to bind us together-our collective honor. Benjamin Sells has stated that "[a]lthough we tend to think of ethics in more philosophical, moralistic terms, it is also a psychological reality that permeates all aspects of

250. J. William Fulbright, The Arrogance OF Power 254-55 (1966).

251. EDITH HAMILTON, THE ROMAN WAY 81 (1932).

252. See id. at 80-81.

253. Velleius Paterculus, Historiae Romanae 2.66.5, in VelleiUs PATERCUlus AND ReS Gestae Divi Augusti 2, 193 (Frederick W. Shipley trans., Harvard Univ. Press 1924) (30 A.D.). 
thought and action. How we think about ethics cannot be divorced from how we imagine our own souls." 254 The same is true for the way in which we imagine natural law principles and our respect for promises.

Refusing to make a promise by which we cannot abide is perfectly acceptable. In fact, it is far more honorable than swearing an oath, only later to perjure it. However, repeated refusal to negotiate meaningfully and to pledge American faith withdraws the United States from the community of nations and from the natural law dialogue. I believe that we can do better, and the swelling tide of international law indicates that we shall have no choice. Steeped in the traditions of Rome and the exemplum of Regulus, we must restore our sense of collective dignity, resanctify the promise, and reenter the natural law dialogue. Only then shall we happily behold a new iconography of faith and an invigorated, august nomen Americanum. 